\title{
Synthesis and reactivity toward olefin exchange and oxidative addition of some platinum( 0 ) olefin complexes with thioquinolines as spectator ligands
}

\author{
Luciano Canovese $^{\mathrm{a}, *}$, Fabiano Visentin ${ }^{\mathrm{a}}$, Thomas Scattolin ${ }^{\mathrm{a}}$, Claudio Santo ${ }^{\mathrm{a}}$, Valerio Bertolasi ${ }^{\mathrm{b}}$ \\ a Dipartimento di Chimica, Università Ca' Foscari, Venice, Italy \\ ${ }^{\mathrm{b}}$ Dipartimento di Chimica and Centro di Strutturistica Diffrattometrica Università di Ferrara, Ferrara, Italy
}

\section{A R T I C L E I N F O}

\section{Article history:}

Received 27 February 2017

Accepted 25 March 2017

Available online 4 April 2017

\section{Keywords:}

Thioquinoline $\mathrm{Pt}(0)$ complexes

Olefin exchange

Alkyl halides oxidative addition

Reaction mechanism

$\mathrm{X}$-ray structural determination

\begin{abstract}
A B S T R A C T
We have synthesized and fully characterized by NMR, IR and elemental analysis sixteen $\mathrm{Pt}(0)$ derivatives stabilized by four different thioquinoline spectator ligands and four different deactivated olefins. Moreover we have studied the reactivity and proposed a mechanism for olefin-olefin, olefin-alkyne exchange and oxidative addition of alkyl halides to this new class of $\operatorname{Pt}(0)$ derivatives based on detailed kinetic measurements. The kinetic study was carried out by NMR and UV-Vis techniques and in one case we have determined the activation parameters. Finally, we were able to resolve the solid state structure of a couple of diastereoisomers among the four possible isomers generated by the combination of two stereocenters.
\end{abstract}

(c) 2017 Elsevier Ltd. All rights reserved.

\section{Introduction}

The metals of the 10th group have been extensively studied owing to their activity as homogeneous catalysts in several industrial processes. In particular, palladium complexes represent an almost inexhaustible source of investigation for many scientists in the field of homo- [1] and hetero-cross coupling [2] catalysis thanks to the easy interconversion between $\operatorname{Pd}(0)$ and $\operatorname{Pd}(\mathrm{II})$ oxidation states.

Comparatively, platinum complexes are less studied although their activity was widely reviewed [3] and their remarkable performance as catalysts in some processes such as alkene and alkyne di-borination [4], alkyne silo-borination [5] or conjugate diene dimerization [6] has been well documented.

The feasibility of the above mentioned reactions is again traceable back to the easiness of interconversion between oxidation states of platinum since the progress of the reactions is governed by the alternation of oxidative additions, reductive eliminations combined with the possible displacement of one ligand with the consequent release of a coordination site. These processes involve 14 or 16 electron species as already established since more than 50 years [7].

\footnotetext{
* Corresponding author.

E-mail address: cano@unive.itl (L. Canovese).
}

Recently, the synthesis of the key intermediates in the homogeneous catalysis by $\mathrm{d}^{10} \mathrm{PtL}_{2}$ involving $\mathrm{NHC}$ [8] or phosphine [9] ligands has represented the goal of some research groups. However, in our opinion the same target can also be reached by the wise catalytic application of olefin complexes of palladium(0) or platinum(0) from which the labile olefin can be easily displaced with the consequent release of a coordination site.

Our group has gained a consolidated experience in the field of palladium $(0)$ olefin complexes and in this respect a rank among the coordinative capabilities of different olefins and alkynes was assessed and the relative stability imparted to their derivatives clearly measured [10]. Remarkably, such a stability order was confirmed also in the case of the less investigated platinum derivatives [11]. Moreover, it was also clear that the nature of the spectator ligands is also important since a comparison of stabilities of olefin complexes can only be carried out within strictly homologous series of compounds [12]. Therefore a thorough knowledge of the nature of the olefins and ligands and their possible interplay is necessary, since these factors strongly modulate the stability and consequently the reactivity of the ensuing complexes [13]. In the last analysis this is a focal point for the final catalyst design.

We therefore decided to study in detail the reactivity toward olefin-olefin, olefin-alkyne exchange and oxidative addition of alkyl halides of the new class of $\operatorname{Pt}(0)$ derivatives stabilized by the bidentate thioquinoline ligands reported in the following Scheme 1. As a matter of fact, the quinoline are flat and rigid 


$$
\mathrm{Pt}(\mathrm{DBA})_{2}+\mathrm{N}-\mathrm{S}+\mathrm{ol} \stackrel{\mathrm{THF}}{\longrightarrow}\left[\mathrm{Pt}(\mathrm{N}-\mathrm{S}) \eta^{2}-\mathrm{Ol}\right]+2 \mathrm{DBA}
$$<smiles>[R]Sc1cccc2ccc([R])nc12</smiles>

$$
\begin{array}{lc}
\mathrm{R}=\mathrm{H} & \mathrm{R}=\mathrm{Me} \\
\mathrm{R}^{\prime}=\mathrm{Me},(\mathbf{1}) & \mathrm{R}^{\prime}=\mathrm{Me},(\mathbf{3}) \\
\mathrm{R}^{\prime}=\mathrm{t}-\mathrm{Bu},(\mathbf{2}) & \mathrm{R}^{\prime}=\mathrm{t}-\mathrm{Bu}, \mathbf{( 4 )}
\end{array}
$$<smiles>O=C1C=CC(=O)O1</smiles>

ol

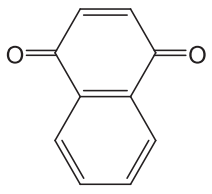

$\mathrm{nq}(\mathbf{d})$

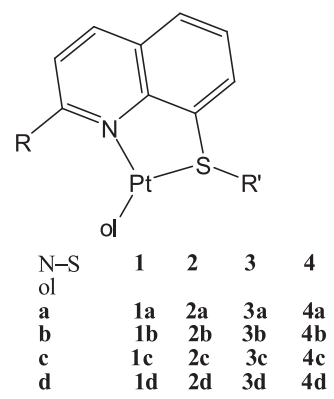

Scheme 1. Reaction and synthesized Platinum(0) olefin complexes stabilized by bidentate thioquinoline ligands.

ligands and their palladium derivatives have recently shown an unexpected reactivity and behavior [14] and therefore seem to us worthy of comparison with the complexes of the less rigid and widely investigated pyridyl-thioether or pyridyl-carbaldiimine ligands [11-13]. The results of our investigation are reported in the present paper.

\section{Result and discussion}

\subsection{Synthesis of the platinum thioquinoline- olefin complexes}

The reaction of the complex $\operatorname{Pt}(\mathrm{DBA})_{2}$ [15] with the ligands $\mathbf{1}, \mathbf{2}$, [16] $\mathbf{3}$ [13c] and 4 [17] in THF and the olefins a-d, at temperatures and reaction times preliminarily determined (see Section 4) gives the $\operatorname{Pt}(0)$ olefin derivatives in $50-60 \%$ yield which is acceptable for this class of compounds. The complexes, when separated from the solvent and dried, are stable for long time at low temperature whereas in solution their stability is reduced and generally variable but usually sufficient for their complete characterization.

The reaction, ligands, olefins and the synthesized complexes are reported in the following Scheme 1.

A downfield shift of the ${ }^{1} \mathrm{H}$ NMR signals of the thioquinoline moieties is observed upon coordination. The thioquinoline protons nearest to the metal undergo a more marked downfield shift and are characterized by satellites due to coupling with ${ }^{195} \mathrm{Pt}$. Thus, the $\mathrm{S}-\mathrm{CH}_{3}$ protons of 1a-d and the quinolinic $\mathrm{H}^{2}$ of $\mathbf{1 a - d}$ and $\mathbf{2 a -}$ d complexes resonate at $\sim 0.4 \mathrm{ppm}\left(\mathrm{J}_{\mathrm{Pt}-\mathrm{H}} \approx 50 \mathrm{~Hz}\right)$ and within $0.3-07 \mathrm{ppm}\left(\mathrm{J}_{\mathrm{Pt}-\mathrm{H}} \approx 50 \mathrm{~Hz}\right)$ downfield with respect to those of the free ligands, respectively. Similar shifts are also detected in the case of the methyl protons in position 2 of the quinoline ring of the complexes 3a-d and $\mathbf{4 a - d}$ resonating at $0.4 \mathrm{ppm}\left(\mathrm{J}_{\mathrm{Pt}-\mathrm{H}} \approx 8-\right.$ $9 \mathrm{~Hz}$ ) downfield of the uncoordinated ligand. ${ }^{13} \mathrm{C}$ NMR spectra display similar behavior and downfield shifts of the signals with the characteristic satellites are detected also in this case.

The coordination of the olefin can be also detected by the NMR and IR spectra of the reaction products as detailed in the following points: i. Owing to the heteroditopicity of the thioquinoline ligands the used olefins display a couple of AX (sometimes AB) signals with coupling constants $\mathrm{J}_{\mathrm{H}-\mathrm{H}}$ in the ranges 7.8-7.9 and 8.4-8.7 Hz when the type E olefins fumaronitrile (b) and dimethylfumarate (a) are taken into account in the order, whereas the $\mathrm{J}_{\mathrm{H}-\mathrm{H}}$ of type $\mathrm{Z}$ moieties ranges within 3.7-3.9 and $6.3-6.6 \mathrm{~Hz}$ in the case of maleic anhydride (c) and naphthoquinone (d), respectively.

ii. The satellite signals due to coordinated olefins display a JPt-H and $\mathrm{J}_{\mathrm{Pt}-\mathrm{C}}$ in the range of $70-80$ and $30-40 \mathrm{~Hz}$, respectively.

iii. An upfield shift of the coordinated olefin protons ( $\sim 3 \mathrm{ppm})$ and carbons ( $\sim 100 \mathrm{ppm}$ ) due to the electronic $\pi$-back donation from the metal to olefin antibonding orbitals is clearly observed in any synthesized complex.

iv. The IR spectra of the isolated complexes display the characteristic $v_{\mathrm{CN}}$ or $v_{\mathrm{CO}}$ stretching.

A selection of ${ }^{1} \mathrm{H},{ }^{13} \mathrm{C}$ NMR and IR spectra are reported in Figs. S1-S5 in the Supplementary Material.

Remarkably, the NMR spectra recorded at RT indicate the presence in solution of only one species although the presence of two different chiral centers, namely the $\mathrm{sp}^{3}$ sulfur and the coordination mode of the olefin ( $\mathrm{Si}$ or Re in the case of type E-olefins and Exo or Endo for Z-olefins) would indicate that two diastereoisomers and the related enantiomers are possible (See Fig. S6, Supplementary Material).

As a matter of fact, decreasing the temperature in the interval of $240-190 \mathrm{~K}$ depending on the studied complexes, causes the appearance of two different groups of signals clearly ascribable to two different diastereoisomers. We report in Fig. 1 the variable temperature ${ }^{1} \mathrm{H}$ NMR spectra of the complex $\mathbf{1 c}$ and in Table 1 the isomeric ratios measured for all the investigated thioquinoline complexes. Notably, a geometric optimization based on DFT calculations seems to indicate that endo isomers are preferred with $\mathrm{Z}$ type olefins whereas RRe (or SSi) isomers are more stable than their analogs $R S i$ (or SRe) with E type olefins (Table S1, Supplementary Material). 


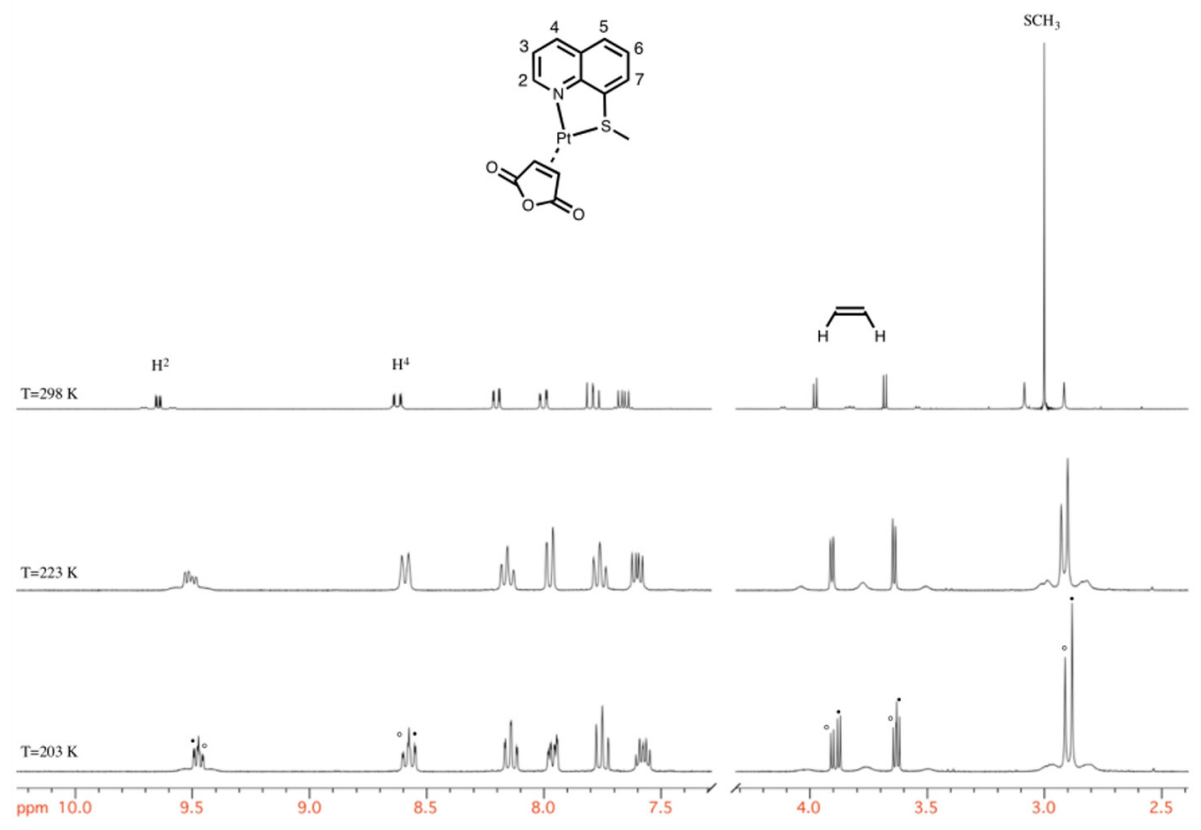

Fig. 1. ${ }^{1} \mathrm{H}$ NMR spectra of complex $1 \mathrm{c}$ in $\mathrm{CD}_{2} \mathrm{Cl}_{2}$ recorded at different temperatures.

Table 1

Isomeric ratio measured by NMR technique (freezing temperatures: ${ }^{\mathrm{a}} 233$; ${ }^{\mathrm{b}} 223$; ${ }^{\mathrm{c}} 203$; $\left.{ }^{\mathrm{d}} 93 \mathrm{~K}\right)$.

\begin{tabular}{lllll}
\hline & $\mathbf{1}$ & $\mathbf{2}$ & $\mathbf{3}$ & $\mathbf{4}$ \\
\hline $\mathbf{a}$ & $4^{\mathrm{c}}$ & $3.7^{\mathrm{b}}$ & $3^{\mathrm{c}}$ & $2.8^{\mathrm{b}}$ \\
$\mathbf{b}$ & $1.5^{\mathrm{c}}$ & $1.5^{\mathrm{b}}$ & $2^{\mathrm{d}}$ & $2.3^{\mathrm{b}}$ \\
$\mathbf{c}$ & $1.35^{\mathrm{c}}$ & $2^{\mathrm{b}}$ & $3^{\mathrm{b}}$ & $1.2^{\mathrm{b}}$ \\
$\mathbf{d}$ & $1.6^{\mathrm{c}}$ & $1.8^{\mathrm{c}}$ & $5^{\mathrm{b}}$ & $6.5^{\mathrm{a}}$
\end{tabular}

As a definitive confirmation we report herein the structures of two diatereoisomers fortuitously present in the repeating unit of a single crystal of complex $\mathbf{3 a}$.

The crystal contains two independent molecules in the asymmetric unit displaying different conformations for the dimethylfumarate (dmfu) ligand as shown by the torsion angles $\mathrm{C} 13=\mathrm{C} 12$ C14-O1 of $4(1)$ and $-175(1)^{\circ}$ in molecules of isomer $R S i$ and $S S i$, respectively.

ORTEP [18] views of both the independent $\operatorname{Pt}(0)$ isomers of complex 3a are reported in Fig. 2.

A selection of bond distances and angles and torsion angles is given in Table S2 (Supplementary Material).

The geometry around the Pt center is formally square planar in both the independent isomers, where the four positions around the central Pt are occupied by N1 and S1 atoms of the ligand 3 and by $\mathrm{C} 12$ and $\mathrm{C} 13$ carbon atoms of the dimethylfumarate (dmfu) thanks to a $\eta^{2}$ interaction with the alkene $\mathrm{C}=\mathrm{C}$ moiety. The coordination around Pt1 can also be considered as trigonal planar if one takes the mid-point of the $\mathrm{C}=\mathrm{C}$ alkene double bond as the third coordination position. The $\mathrm{C} 14-\mathrm{C} 12=\mathrm{C} 13-\mathrm{C} 16$ carbon chains of the dmfu ligands are slightly twisted, displaying torsion angles of 145.3(8) and $145.5(9)^{\circ}$ in the independent molecules of isomers $R S i$ and SSi, respectively. In both the isomers, the $\mathrm{C} 12=\mathrm{C} 13$ double bonds are lengthened to 1.443(12) and 1.471(12) Å as observed in other similar complexes.

\subsection{Synthesis of the platinum thioquinoline- alkyne complexes}

Platinum and palladium olefin complexes stabilized by thioquinoline spectator ligands give different products when reacting with deactivated alkynes. Palladium olefin complexes yield palladacyclometallate species even under stoichiometric conditions $[13 c, d]$ whereas in the case of the reaction of complex 2a with the alkynes dimethyl but-2-ynedioate (DMA), diethyl but-2ynedioate (DEtA) and dit-butyl but-2-ynedioate (DtBA) only the alkyne derivatives obtained in the presence of the entering alkyne in marked excess were observed (See Scheme 2).

Complex 2e was synthesized, separated in 70\% yield and characterized by a detailed ${ }^{1} \mathrm{H}$ and ${ }^{13} \mathrm{C}$ NMR investigation as can be seen in the spectra reported in the Supplementary Material (Figs. S7-S8).

In the ${ }^{1} \mathrm{H}$ NMR spectrum the signals ascribable to the ligand $\mathbf{2}$ are downfield with respect to those of the free ligand. In particular the $\mathrm{H}^{2}$ proton resonating at $10.3 \mathrm{ppm}$ displays two satellites due to the coupling with ${ }^{195} \mathrm{Pt}$ with $\mathrm{J}_{\mathrm{Pt}-\mathrm{H}}=37.6 \mathrm{~Hz}$. Owing to the heteroditopicity of the ligand, the methyl protons and carbons of DMA resonate as two distinct singlets at 3.86 and 3.92 and at 109.4 and $118.9 \mathrm{ppm}$, respectively. The considerably high field resonance of the unsaturated carbons of the coordinate alkyne (free alkyne resonates at $152.5 \mathrm{ppm}$ ) suggests a remarkable $\pi$-back donation with the consequent formation a platina-cyclopropyne structure.

Finally, the characterization was completed by IR spectroscopy $\left(v_{\text {Coome }}=1750 \mathrm{~cm}^{-1}\right)$ and elemental analysis (See Section 4$)$.

It is however noteworthy that the reaction in Scheme 2 does not represent the general rule since the NMR spectra obtained in the case of complexes with different olefin or thioquinoline ligands suggest the formation of a mixture of different derivatives that cannot be easily interpreted.

\subsection{Oxidative addition}

The oxidative addition and the related reductive elimination are remarkably important processes in the field of homo-[1] and hetero-cross coupling [2]. For such a reason, we have recently studied some oxidative reactions of $\mathrm{Pd}(\mathrm{II})$ or $\mathrm{Pd}(0)$ complexes involving halogens, interhalogens, $[14 \mathrm{c}, 19]$ and alkyl or aryl halides $[13 \mathrm{~g}, 16,20]$. In the search for analogies or differences with palladium derivatives, if any, we decided to investigate the oxidative addition of complexes $\mathbf{2 a}$ and $\mathbf{4 a}$ with allyl chloride 

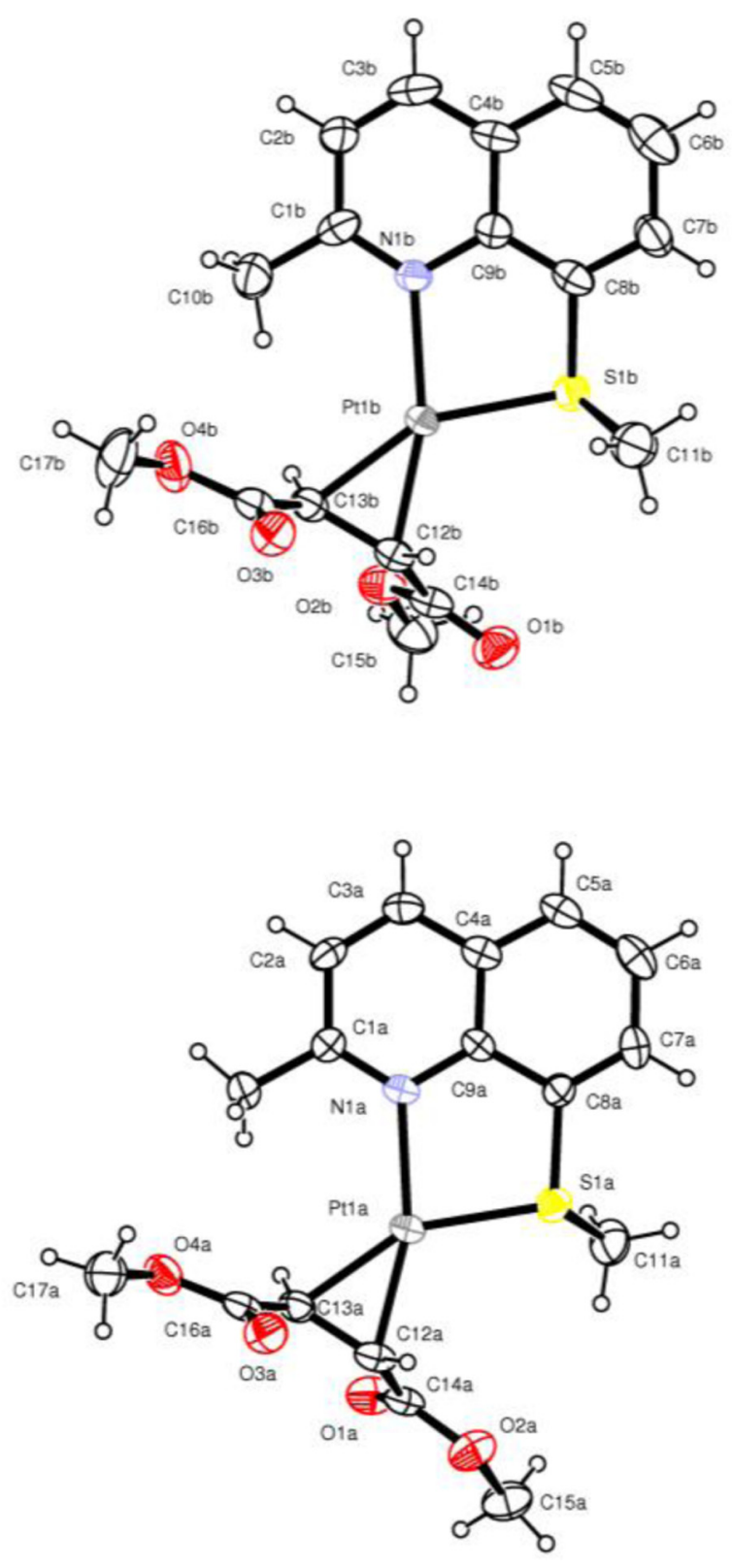

Fig. 2. ORTEP [18] view of the diastereoisomers of complex 3a showing the thermal ellipsoids at $40 \%$ probability level. Isomer $R S i$ (top) and SSi (bottom).

and 3-chloro-1-phenylpropyne which are the most reactive species among the commercially available alkyl halides. Concomitantly, complexes $\mathbf{2 a}$ and $\mathbf{4 a}$ display the highest reactivity among the investigated $\operatorname{Pt}(0)$ species thanks to dmfu which is the most weakly coordinated olefin and hence the most prone to displacement [10].

\subsubsection{Reaction of complex $\mathbf{2 a}$ with allyl chloride}

The studied reaction is summarized in the following Scheme 3:

Complex 2a turned out as the more suitable for a quantitative study involving its oxidative addition with allylchloride. The investigation was first followed by NMR and thereafter complex $\mathbf{2 h}$ was synthesized, separated and characterized by ${ }^{1} \mathrm{H},{ }^{13} \mathrm{C}$ NMR spectra and elemental analysis (See Section 4). As can be deduced from the NMR spectra, at variance with similar palladium complexes which give derivatives bearing the allyl fragment $\eta^{3}$-coordinated, complex 2a yields exclusively the $\eta^{1}$-coordinated one.

The $\mathrm{AB}$ part of an $\mathrm{ABCX}$ multiplet generated by the diastereotopic $\mathrm{CH}_{2 \alpha}$ ( $\mathrm{C}$ in this case represents proton $\mathrm{H}_{\beta}$, whereas $\mathrm{X}$ corresponds to ${ }^{195} \mathrm{Pt}$ ) can be simulated despite its particular complexity due to the coupling constant interplay (See Fig. S9B Supplementary Material). Further, resonance frequencies are observed at ca. $2.9 \mathrm{ppm}$ (alkyl protons $\mathrm{CH}_{2 \alpha}$ ) and in the interval 4.7-6.2 ppm (olefin protons $\mathrm{H}_{\beta}, \mathrm{H}_{\gamma}$ trans and $\mathrm{H}_{\gamma}$ cis with respect to $\mathrm{H}_{\beta}$, with $\mathrm{J}_{\mathrm{HH}}=17.1$ and $9.9 \mathrm{~Hz}$, respectively) and at $6.2 \mathrm{ppm}$ (a multiplet ascribable to the proton $\mathrm{H}_{\beta}$. These facts point to the $\eta^{1}$-coordination mode of the allyl fragment.

Moreover, the ${ }^{1} \mathrm{H}$ NMR spectrum suggests the position of chloride with respect to quinoline nitrogen since the remarkably low field resonance of the quinolinic $\mathrm{H}^{2}(10.2 \mathrm{ppm})$ is typical of a $\mathrm{H}^{2}$ proton cis to chloride [14 and Refs. therein]. Consistently, the ${ }^{13} \mathrm{C}$ NMR spectrum displays the carbons of the allyl fragment resonating at three distinct frequencies at $146.2\left(C_{\beta}\right), 107.1\left(C_{\gamma}\right)$ and $1.3\left(\mathrm{C}_{\alpha}\right)$ ppm. In particular, the resonance of the latter being detected at high field owing to its direct coordination to the metal.

We have elsewhere proposed a mechanism for similar reactions of allylchloride with homologous palladium derivatives which involves slow formation of a pentacoordinated intermediate followed by fast release of dmfu and concomitant formation of the reaction product $[13 \mathrm{~g}, 16]$. This sort of reactions, carried out either under stoichiometric or almost stoichiometric conditions, is aptly described by a second order decay of the starting complex and concomitant formation of the reaction product.

The reaction of complex $\mathbf{2 a}$ with allylchloride behaves similarly and as can be seen in Supplementary Material (Fig. S11) the rate law and the concentration changes vs. time followed by ${ }^{1} \mathrm{H}$ NMR indicate a second order mechanism. Expectedly, the reactivity of the homologous palladium complex $\left(k_{2(\mathrm{Pd})}=0.294 \pm 0.009 \mathrm{dm}^{3} \mathrm{~mol}^{-1} \mathrm{~s}^{-1}\right)$ [16] is considerably higher than that measured for platinum $\left(\mathrm{k}_{2(\mathrm{Pt})}=(8.7 \pm 0.4) \times 10^{-3} \mathrm{dm}^{3}\right.$ $\left.\mathrm{mol}^{-1} \mathrm{~s}^{-1}\right)$.

\subsubsection{Reaction of complexes $2 \boldsymbol{a}$ and $\mathbf{4 a}$ with 3-chloro-1- phenylpropyne}

In Scheme 4 we condense the experimental evidence gathered from the NMR spectra reported in Figs. S12-14 (Supplementary
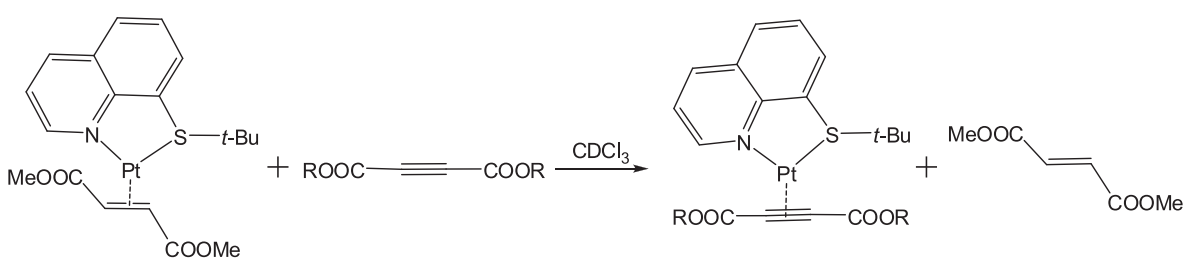

$$
\begin{aligned}
& \mathrm{R}=\mathrm{Me} ; \quad \mathrm{DMA}(\mathrm{e}) \quad 2 \mathrm{e} \\
& \mathrm{R}=\mathrm{Et} ; \quad \mathrm{DEtA}(\mathrm{f}) \quad 2 f \\
& \mathrm{R}=t-\mathrm{Bu} ; \mathrm{DtBA}(\mathrm{g}) \quad 2 \mathrm{~g}
\end{aligned}
$$

Scheme 2. Synthesis of Platinum thioquinoline alkyne complexes 2e-g. 


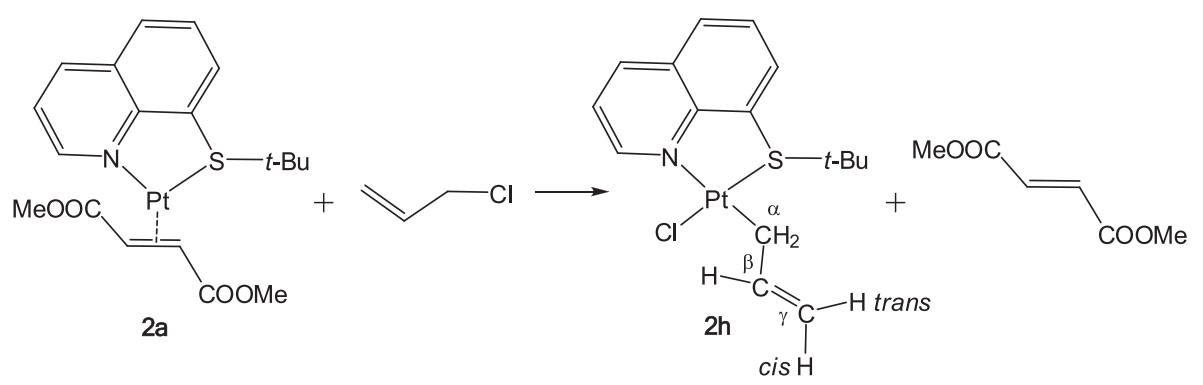

Scheme 3. Oxidative addition of allylchloride to complex 2a.

Material). The reactivity of dmfu derivatives $\mathbf{2 a}$ and $\mathbf{4 a}$ is influenced by the substituent in position 2 of the thioquinoline ring. Thus, complex 2a reacts with 3-chloro-1-phenylpropyne yielding an almost equimolecular tautomeric mixture of $\mathbf{2 i}$ and $\mathbf{2 j}$ whereas complex $4 \mathbf{a}$ gives exclusively the allenyl tautomer $\mathbf{4 i}$ in the course of several hours (ca. $24 \mathrm{~h}$ ).

Unfortunately, the tautomeric mixture (2i, $\mathbf{2 j}$ ), although obtainable in microcrystalline form under preparative conditions, is not stable enough in solution and therefore its ${ }^{13} \mathrm{C}$ NMR spectrum was not recorded. The ${ }^{1} \mathrm{H}$ NMR spectrum (Fig. S12, Supplementary Material) however clearly displays two low field doublets ( $\geq 10 \mathrm{ppm}$ ) ascribable to $\mathrm{H}^{2}$ thioquinoline ring cis to chloride for both tautomers, the typical $\mathrm{AB}$ signal of the diastereotopic $\mathrm{CH}_{2}$ propargylic protons at $2.62-2.82 \mathrm{ppm}\left(\mathrm{J}_{\mathrm{Pt}-\mathrm{H}}=100.7 \mathrm{~Hz}\right)$ and the singlet at $4.56 \mathrm{ppm}$ of the $\mathrm{CH}_{2}$ protons of the allenyl species.

Complex 4a reacts with 3-chloro-1-phenylpropyne to give almost exclusively the allenyl isomer 4i. Quite surprisingly when a similar reaction was carried out with the analogous palladium derivative the propargyl tautomer was obtained almost quantitatively. A dedicated DFT investigation supports these experimental findings. Thus, the palladium propargyl derivative turned out to be more stable than its allenyl counterpart by ca. $0.9 \mathrm{kcal} \mathrm{mol}^{-1}$ [13g] whereas in the present case the platinum allenyl species is more stable by ca. $0.5 \mathrm{kcal} \mathrm{mol}^{-1}$ than the propargyl isomer. The ${ }^{1} \mathrm{H}$ and ${ }^{13} \mathrm{C}$ NMR spectra reported in the Supplementary Material (Figs. S13 and 14) display the presence in solution of a unique species with the methyl group in position 2 of the thioquinoline ligand resonating as a singlet 0.5 downfield with respect to the free ligand (again indicating the chloride in cis position). Moreover, the diastereotopic allenyl protons at $4.6 \mathrm{ppm}$ and the allenyl carbons at $68.9\left(=\mathrm{CH}_{2}\right), 76.2(\mathrm{Pt}-\mathrm{C}-\mathrm{Ph})$ and $204.7(=\mathrm{C}=)$ ppm, confirm the allenylic nature of the isomer.

\subsection{Olefin exchange reactions}

As already stated the displacement of a ligand from a metal complex may be a keystone governing the catalytic activity of the complex itself. In this respect the strength of the metal-olefin bond is crucial and the related coordinative capability of one olefin can be easily measured by competitive reactions with other alkenes or alkynes and the hierarchy straightforwardly established [10]. However, the coordinative capability of the olefins does not depend on their electronic properties only but rather, on the interplay of such characteristics and the nature of the spectator ligands and metal. Thus, although the gross reactivity order remains unchanged, any fine determination is confined within strictly homologous series of compounds. In this respect, we have undertaken a systematic kinetic study of the olefin-olefin and olefinalkyne exchange in thioquinoline platinum olefin complexes by the reliable UV-Vis technique. Remarkably, at variance with the fast equilibrium reaction characterizing palladium derivatives, platinum complexes react slowly and quantitatively according to the reactions summarized in the following Scheme 5 .

We have therefore firstly identified the favorable absorbance changes by recording the absorbance vs. wavelength spectra of the reaction under study and then the absorbance $v s$. time changes at a suitable wavelength under pseudo-first order conditions ([ $\mathrm{ol}_{1}$ (alk) $]_{0} /[\text { Complex }]_{0} \geq 10$ ). The reactions went smoothly to completion and the final spectrum was coincident with that of an authentic sample of the reaction product recorded under the same experimental conditions. All the reactions obey to the monoexponential law:

$D_{t}-D_{\infty}=\left(D_{0}-D_{\infty}\right) e^{-k_{o b s} * t}$

where $D_{0}, D_{\infty}$ and $D_{t}$ represent the initial, the final and the absorbance at time $t$, respectively, whereas $\mathrm{k}_{\mathrm{obs}}\left(\mathrm{s}^{-1}\right)$ is the determined pseudo-first order rate constant (See Supplementary Material Figs. S15 and 16).

The linear regression of the ensuing $\mathrm{k}_{\mathrm{obs}}=\mathrm{k}_{2}\left[\mathrm{ol}_{2} \text { (alk) }\right]_{\text {in excess }}$ values vs. the olefin or alkyne concentrations displays no significant intercept, thereby suggesting the rate law:

$-\frac{d[\text { Complex }]}{d t}=k_{2}[$ Complex $]\left[\mathrm{ol}_{2}(\right.$ alk $\left.)\right]$

The slope of the straight line gives the second order rate constants $k_{2}$ which we took as a measurement of the relative coordinative capability of the studied olefins or alkynes (See Supplementary Material Fig. S17).

However, in the case of fast reactions the experimental approach described above is no longer possible. We therefore resorted to experiments carried out under second order conditions in which the concentrations of both complex and entering olefin are in almost stoichiometric ratio. In this case the absorbance vs. time profiles are described by the relationship:

$D_{t}=\frac{\left(D_{0}-D_{\infty}\right) \Delta_{0}}{\left[o l_{2}(\text { alk })\right]_{0} e^{k_{2} \Delta_{0} t}-[\text { Complex }]_{0}}+D_{\infty}$

where $[\text { Complex }]_{0}$ and $\left[\mathrm{ol}_{2}(\mathrm{alk})\right]_{0}$ are the initial concentrations of complex and entering olefin (or alkyne) and $\Delta_{0}=$ $\left[\mathrm{ol}_{2}(\mathrm{alk})\right]_{0}-[\text { Complex }]_{0}$ (with $\left[\mathrm{ol}_{2}(\text { alk })\right]_{0}>[\text { Complex }]_{0}$ ). We have thus been able to determine the rate constant of the fastest reactions and confirmed the second order nature of the reaction under study.

In order to assess the intimate mechanism we have also measured in one case the temperature dependence of $\mathrm{k}_{2}$ according to the Eyring approach. The ensuing values of activation parameters for the reaction of $2 d$ with DMA are $\Delta H^{\#}=45 \pm 2 \mathrm{~kJ} / \mathrm{mol}$ and $\Delta S^{\#}=-95 \pm 6 \mathrm{~J} / \mathrm{mol}$. The negative entropy value definitely points to a typical associative exchange process in which the entering alkyne and the leaving olefin are both coordinated in the reaction intermediate (See Table S4 and Fig. S18 in Supplementary Material). Thus, the complete representation of the reaction taking into account the hypothesized intermediate can be represented by the following Scheme 6:

The determined $\mathrm{k}_{2}$ values are summarized in the following Table 2 . 

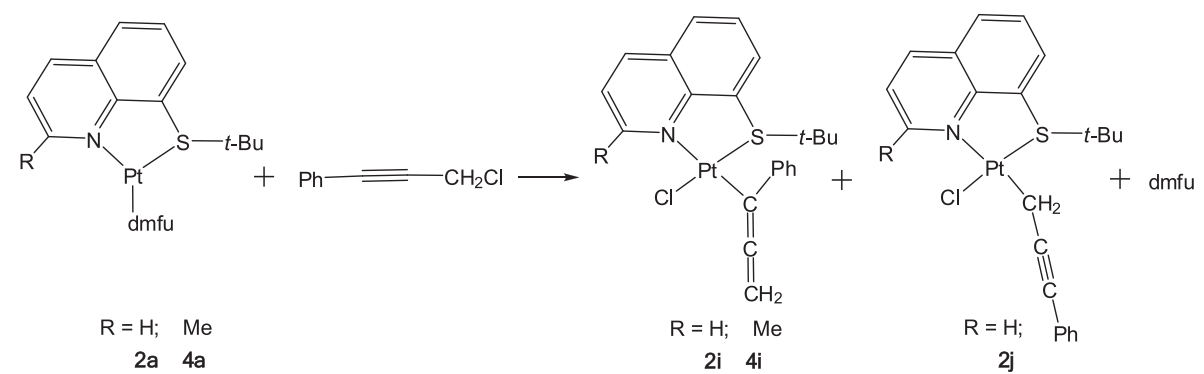

Scheme 4. Oxidative addition of 3-chloro-1-phenylpropyne on complexes 2a and $4 \mathbf{a}$.

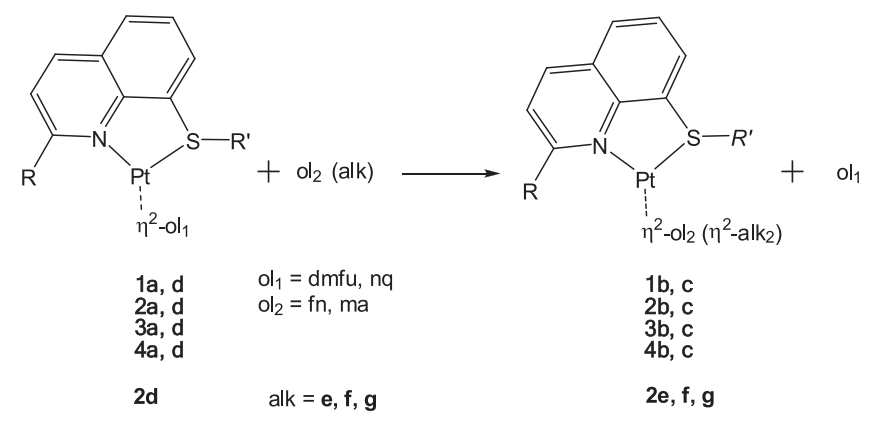

Scheme 5. Olefin-olefin or olefin-alkyne exchange reaction.

From the comparison among data it is apparent that steric hindrance of the reactants is of primary importance as expected for reactions in which an associative mechanism is involved. In particular:

i) The $k_{2}$ value is heavily influenced (at least by one order of magnitude) by the substituent at sulfur. As a matter of fact, the reactivity of the less hindered complexes increases by about two orders of magnitude (complexes 1d, 3d vs. 2d, 4d). The methyl substituent at the quinoline ring also influences the reactivity by lowering the rate constants by about one or two orders of magnitude (complexes 1d, 2d vs. 3d, 4d).

ii) A monotonic decrease albeit small, of the rate constants due to the increasing steric hindrance of the substituent is also noticed when the rates of the entering alkynes are compared (see reactions between complex $\mathbf{2 d}$ and alkynes).

As for the olefin or alkynes involved in the substitution reaction it is apparent that:

i) Among the studied olefins, dmfu is the best leaving moiety owing to its weakest bond with platinum. Such a comparatively weak bond is due to its reduced electron withdrawing characteristics as noticed in previously published studies on $\operatorname{Pd}(0)$ and $\mathrm{Pt}(0)$ complexes $[10,11]$. ii) Olefin c (ma) is the best entering moiety despite its electron withdrawing characteristics which are similar to those of $\mathbf{b}$ (fn), probably because of its reduced size [10].

iii) Alkynes are less effective as entering groups than olefins owing to their high $\pi$-electron accepting properties y which hamper the formation of the intermediate (see Scheme 6) by reducing the available electron density at the metal.

Again, all these phenomena are traceable back to an associative mechanism in which the entering and the leaving group are both coordinated in the intermediate

\section{Conclusion}

We have synthesized and characterized some new olefin platinum complexes bearing thioquinoline as ancillary ligands. In one case we were able to resolve the solid state structures of a couple of diastereoisomers which had been firstly detected by NMR spectroscopy. We have obtained some alkyne derivatives by olefin-alkyne exchange. We have also measured the rate of the olefin-alkyne exchange and in the case of complex 2d we have measured the activation parameters which suggest an associative mechanism for the exchange. Such a mechanism was confirmed by a kinetic study carried out also in the case of the olefin-olefin exchange reactions.

Furthermore, we have studied the oxidative addition of allylchloride and 3-chloro-1-phenylpropyne to selected platinum(0) complexes. We have measured the rate constant of the reaction giving the $\eta^{1}$-coordinated allyl derivative $\mathbf{2 h}$ only, when allylchloride reacts with complex 2a (no $\eta^{3}$-derivatives have been observed). In the case of the reaction of 3-chloro-1-phenylpropyne with complexes $\mathbf{4 a}$ and $\mathbf{2 a}$ we have obtained the allenyl tautomer $\mathbf{4 i}$ or the tautomeric mixture $\mathbf{2} \mathbf{i}-\mathbf{2} \mathbf{j}$, respectively.

\section{Experimental}

\subsection{Solvents and reagents}

All the following distillation processes were carried out under inert atmosphere (argon). $\mathrm{CH}_{2} \mathrm{Cl}_{2}$ was firstly treated with $3 \AA$ molecular sieves and thereafter distilled. $\mathrm{CHCl}_{3}$ was distilled over
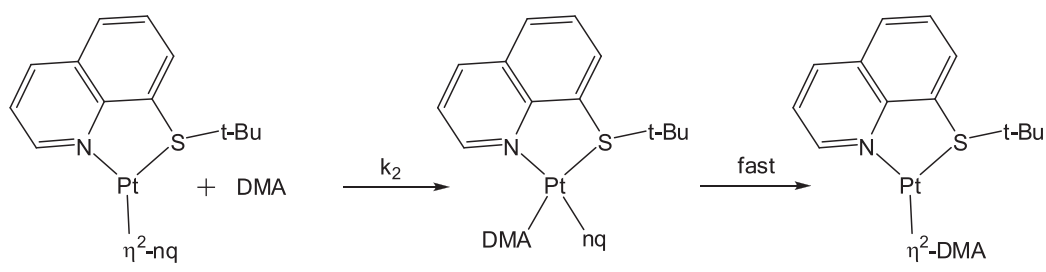

Scheme 6. Proposed mechanism involving an intermediate bearing the leaving olefin and the entering alkyne simultaneously coordinated. 
Table 2

Second-order rate constants $\left(\mathrm{k}_{2} \mathrm{dm}^{3} \mathrm{~mol}^{-1} \mathrm{~s}^{-1}\right)$ for selected complexes as a function of the entering olefin.

\begin{tabular}{|c|c|c|c|c|c|}
\hline & $b(\mathbf{f n})$ & c (am) & e (DMA) & f (DEA) & $\mathrm{g}$ (DtBA) \\
\hline 1d & $(1.46 \pm 0.02) \cdot 10^{3}$ & too fast & 1 & 1 & 1 \\
\hline 2d & $43 \pm 1$ & $150 \pm 2$ & $0.74 \pm 0.02$ & $0.500 \pm 0.006$ & $0.243 \pm 0.004$ \\
\hline 3d & $243.2 \pm 0.8$ & $(2.51 \pm 0.03) \cdot 10^{3}$ & 1 & 1 & 1 \\
\hline 4d & $1.16 \pm 0.02$ & $32 \pm 1$ & $0.264 \pm 0.003$ & i & i \\
\hline $2 a$ & $(2.27 \pm 0.03) \cdot 10^{3}$ & too fast & $3.23 \pm 0.07$ & 1 & 1 \\
\hline $4 a$ & $305 \pm 1$ & 1 & $3.55 \pm 0.07$ & 1 & 1 \\
\hline
\end{tabular}

silver foil. Tetrahydrofurane was distilled over benzophenone and metallic sodium. All the other chemicals were commercially available grade products and were used as purchased.

\subsection{Data analysis}

Non linear and linear analysis of the data related to kinetics measurements were performed by locally adapted routines written in ORIGIN $^{\circledR} 7.5$ or SCIENTIST ${ }^{\circledR}$ environments.

\subsection{IR, NMR, UV-Vis and Elemental analysis measurements}

The IR, ${ }^{1} \mathrm{H},{ }^{13} \mathrm{C}$ and ${ }^{31} \mathrm{P}$ NMR spectra were recorded on a PerkinElmer Spectrum One spectrophotometer and on a Bruker 300 Avance spectrometer, respectively. UV-Vis spectra were taken on a Perkin-Elmer Lambda 40 spectrophotometer equipped with a Perkin-Elmer PTP6 (Peltier temperature programmer) apparatus. Elemetal analysis was carried out using an Elementar CHN CUBO Micro Vario analyzer.

\subsection{Preliminary studies and kinetic measurements}

The UV-Vis preliminary study was carried out by placing $3 \mathrm{ml}$ of a freshly prepared solution of the complex under study ([Complex $]_{0}=1 \times 10^{-4} \mathrm{~mol} \mathrm{dm}^{-3}$ ) in the thermostatted $(298 \mathrm{~K})$ cell compartment of the UV-Vis spectrophotometer. Microaliquots of solutions containing the olefin (alkyne) in adequate concentrations ([ol] $=\min 1 \times 10^{-3} \mathrm{~mol} \mathrm{dm}^{-3}$ ) were added and the absorbance changes were monitored in the $280-550 \mathrm{~nm}$ wavelength interval or at an optimized fixed wavelength. Fast reactions have been studied under almost stoichiometric conditions. In such a case the data treatment was carried out by the second-order approach.

\subsection{Computational details}

The geometrical optimization of the complexes was carried out by the Gaussian 09 program [21] without symmetry constraints, using the hyper-GGA functional M06, [22,23] in combination with polarized triple- $\zeta$-quality basis sets (LAN2TZ(f)) [24,25] and relativistic pseudopotential for the Pt atoms, a polarized double- $\zeta-$ quality basis sets (LANL2DZdp) [26] with diffuse functions for the halogen atoms and a polarized double- $\zeta$-quality basis sets (6-31G $(\mathrm{d}, \mathrm{p}))$ for the other elements. Solvent effects $\left(\mathrm{CH}_{2} \mathrm{Cl}_{2}, \varepsilon=9.93\right)$ were included using CPCM $[27,28]$.

The "restricted" formalism was applied in all the calculations. The zero-point vibrational energies and thermodynamic parameters were obtained [29] by means of the stationary points characterized by IR simulation.

All the computational work was carried out on Intel based x 8664 workstations.

\subsection{Crystal structure determinations}

The crystal data of compound 3a were collected at room temperature using a Nonius Kappa CCD diffractometer with graphite monochromated Mo-K $\alpha$ radiation. The data sets were integrated with the Denzo-SMN package [30] and corrected for Lorentz, polarization and absorption effects (SORTAV) [31]. The structure was solved by direct methods using SIR97 [32] system of programs and refined using full-matrix least-squares with all non-hydrogen atoms anisotropically and hydrogens included on calculated positions, riding on their carrier atoms.

All calculations were performed using SHELXL-2014/6 [33] and PARST [34] implemented in winGX [35] system of programs. The crystal data are given in Table S3 and a selection of bond distances and angles is given in Table S2 (Supplementary Information).

\subsubsection{Synthesis of complex $\mathbf{1 b}$}

$0.0602 \mathrm{~g}(0.343 \mathrm{mmol})$ of 8 -methylthioquinoline (1), $0.0480 \mathrm{~g}$ $(0.65 \mathrm{mmol})$ of fumaronitrile $(\mathbf{b})$ and $0.2050 \mathrm{~g}(0.309 \mathrm{mmol})$ of Pt $(\mathrm{DBA})_{2}$ were dissolved in $30 \mathrm{ml}$ of anhydrous THF under inert atmosphere $(\mathrm{Ar})$ in a $100 \mathrm{ml}$ two-necked flask. The mixture was stirred at R.T. for $60 \mathrm{~min}$ and then at $45^{\circ} \mathrm{C}$ for further $60 \mathrm{~min}$. The solution was dried under vacuum and the residue dissolved in $\mathrm{CH}_{2} \mathrm{Cl}_{2}$, treated with activated carbon, filtered on a Celite filter, the volume reduced under vacuum and finally diethyl ether was added. The precipitated pale-brown complex 1b was filtered off on a gooch, repeatedly washed with diethyl ether and $n$-pentane, and finally dried under vacuum. $0.0769 \mathrm{~g}$ (yield 57\%) of the complex $\mathbf{1 b}$ was obtained.

${ }^{1} \mathbf{H}-N M R$ (300 MHz, $\left.\mathbf{C D}_{2} \mathbf{C l}_{2}, \mathbf{T}=\mathbf{2 9 8} \mathbf{K}, \mathbf{p p m}\right) \delta: 2.79(\mathrm{~d}, 1 \mathrm{H}$, $\left.\mathrm{J}=7.8 \mathrm{~Hz}, \quad \mathrm{~J}_{\mathrm{PtH}}=89.1 \mathrm{~Hz}, \mathrm{CH}=\mathrm{CH}\right), 3.05\left(\mathrm{~s}, \mathrm{~J}_{\mathrm{PtH}}=49.0 \mathrm{~Hz}, 3 \mathrm{H}\right.$, $\left.\mathrm{SCH}_{3}\right), 3.11\left(\mathrm{~d}, 1 \mathrm{H}, \mathrm{J}=7.8 \mathrm{~Hz}, \mathrm{~J}_{\mathrm{PtH}}=82.5 \mathrm{~Hz}, \mathrm{CH}=\mathrm{CH}\right), 7.68(\mathrm{dd}$, $\left.1 \mathrm{H}, \mathrm{J}=8.4,4.9 \mathrm{~Hz}, \mathrm{H}^{3}\right), 7.81\left(\mathrm{dd}, 1 \mathrm{H}, \mathrm{J}=8.2,7.3 \mathrm{~Hz}, \mathrm{H}^{6}\right), 8.02(\mathrm{dd}$, $\left.1 \mathrm{H}, \mathrm{J}=8.2,1.2 \mathrm{~Hz}, \mathrm{H}^{5}\right), 8.23\left(\mathrm{dd}, 1 \mathrm{H}, \mathrm{J}=7.3,1.2 \mathrm{~Hz}, \mathrm{H}^{7}\right), 8.65(\mathrm{dd}$, $\left.1 \mathrm{H}, \mathrm{J}=8.4,1.5 \mathrm{~Hz}, \mathrm{H}^{4}\right), 9.70\left(\mathrm{dd}, 1 \mathrm{H}, \mathrm{J}=4.9,1.5 \mathrm{~Hz}, \mathrm{~J}_{\mathrm{PtH}}=35.5 \mathrm{~Hz}\right.$, $\left.\mathrm{H}^{2}\right)$.

${ }^{13} \mathbf{C}\left\{{ }^{1} \mathbf{H}\right\}-N M R\left(\mathbf{C D}_{\mathbf{2}} \mathbf{C l}_{\mathbf{2}}, \mathbf{T}=\mathbf{2 9 8} \mathbf{K}, \mathbf{p p m}\right) \delta: 4.7\left(\mathrm{CH}, \mathrm{J}_{\mathrm{PtC}}=406 \mathrm{~Hz}\right.$ $\mathrm{CH}=\mathrm{CH}), 9.9\left(\mathrm{CH}, \mathrm{J}_{\mathrm{PtC}}=422 \mathrm{~Hz}, \mathrm{CH}=\mathrm{CH}\right), 29.1\left(\mathrm{CH}_{3}, \mathrm{SCH}_{3}\right), 123.3$ $(\mathrm{C}, \mathrm{CN}), 123.5(\mathrm{C}, \mathrm{CN}), 123.9\left(\mathrm{CH}, \mathrm{JPtC}_{\mathrm{PtC}} 41 \mathrm{~Hz}, \mathrm{C}^{3}\right), 128.9\left(\mathrm{CH}, \mathrm{C}^{6}\right)$, $130.2\left(\mathrm{CH}, \mathrm{C}^{5}\right), 130.7\left(\mathrm{C}, \mathrm{J}_{\mathrm{PtC}}=25 \mathrm{~Hz}, \mathrm{C}^{10}\right), 136.3\left(\mathrm{C}, \mathrm{J}_{\mathrm{PtC}}=31 \mathrm{~Hz}\right.$, $\left.\mathrm{C}^{8}\right), 136.8\left(\mathrm{CH}, \mathrm{C}^{7}\right), 138.8\left(\mathrm{CH}, \mathrm{C}^{4}\right), 147.8\left(\mathrm{C}, \mathrm{C}^{9}\right), 157.4(\mathrm{CH}$, $\left.\mathrm{JPtC}_{\mathrm{PtC}}=47 \mathrm{~Hz}, \mathrm{C}^{2}\right)$.

IR, $\mathrm{KBr}$ pellets $\left(\mathrm{cm}^{-1}\right): v_{\mathrm{CN}}=2200$.

Elemental anal. (\%) for $\mathrm{C}_{14} \mathrm{H}_{11} \mathrm{~N}_{3}$ PtS: C 37.50, H 2.47, N 9.37. Found: C 37.37, H 2.51, N 9.21.

The following complexes were obtained according to the above described protocols using the appropriate starting complexes and olefins. The yield, color, reaction time and, where necessary, some supplementary information will be reported under the title.

\subsubsection{Synthesis of complex $\mathbf{1 a}$}

Reaction time: $60 \mathrm{~min}$. Temperature: $45^{\circ} \mathrm{C}$. Yield 55\%. Color: yellow. 
${ }^{1} \mathbf{H}-\mathrm{NMR}$ (300 MHz, $\left.\mathbf{C D}_{\mathbf{2}} \mathbf{C l}_{2}, \mathbf{T}=\mathbf{2 9 8} \mathbf{K}, \mathbf{p p m}\right) \delta: 2.94(\mathrm{~s}$, $\left.\mathrm{J}_{\mathrm{PtH}}=50.0 \mathrm{~Hz}, 3 \mathrm{H}, \mathrm{SCH}_{3}\right), 3.58\left(\mathrm{~d}, 1 \mathrm{H}, \mathrm{J}=8.5 \mathrm{~Hz}, \mathrm{JPtH}_{\mathrm{PtH}}=93.2 \mathrm{~Hz}\right.$, $\mathrm{CH}=\mathrm{CH}), 3.61\left(\mathrm{~s}, 6 \mathrm{H}, \mathrm{OCH}_{3}\right), 3.69\left(\mathrm{~s}, 6 \mathrm{H}, \mathrm{OCH}_{3}\right), 3.91(\mathrm{~d}, 1 \mathrm{H}$, $\left.\mathrm{J}=8.5 \mathrm{~Hz}, \mathrm{~J}_{\mathrm{PtH}}=87.3 \mathrm{~Hz}, \mathrm{CH}=\mathrm{CH}\right), 7.62(\mathrm{dd}, 1 \mathrm{H}, \mathrm{J}=8.4,4.9 \mathrm{~Hz}$, $\left.\mathrm{H}^{3}\right), 7.74\left(\mathrm{dd}, 1 \mathrm{H}, \mathrm{J}=8.2,7.3 \mathrm{~Hz}, \mathrm{H}^{6}\right), 7.96(\mathrm{dd}, 1 \mathrm{H}, \mathrm{J}=8.2,1.2 \mathrm{~Hz}$, $\left.\mathrm{H}^{5}\right), 8.16\left(\mathrm{dd}, 1 \mathrm{H}, \mathrm{J}=7.3,1.2 \mathrm{~Hz}, \mathrm{H}^{7}\right), 8.59(\mathrm{dd}, 1 \mathrm{H}, \mathrm{J}=8.4,1.5 \mathrm{~Hz}$, $\left.\mathrm{H}^{4}\right), 9.68\left(\mathrm{dd}, 1 \mathrm{H}, \mathrm{J}=4.9,1.5 \mathrm{~Hz}, \mathrm{~J}_{\mathrm{PtH}}=35.8 \mathrm{~Hz}, \mathrm{H}^{2}\right)$.

${ }^{13} \mathbf{C}\left\{{ }^{1} \mathbf{H}\right\}-N M R\left(\mathbf{C D}_{\mathbf{2}} \mathbf{C l}_{\mathbf{2}}, \mathbf{T}=\mathbf{2 9 8} \mathbf{K}, \mathbf{p p m}\right) \delta: 28.5\left(\mathrm{CH}, \mathrm{J}_{\mathrm{PtC}}=359 \mathrm{~Hz}\right.$ $\mathrm{CH}=\mathrm{CH}), 28.7\left(\mathrm{CH}_{3}, \mathrm{SCH}_{3}\right), 35.1\left(\mathrm{CH}, \mathrm{J}_{\mathrm{PtC}}=350 \mathrm{~Hz}, \mathrm{CH}=\mathrm{CH}\right), 50.6$ $\left(\mathrm{CH}_{3}, \mathrm{OCH}_{3}\right), 50.7\left(\mathrm{CH}_{3}, \mathrm{OCH}_{3}\right), 123.7(\mathrm{CH}, \mathrm{JPtC}=40 \mathrm{~Hz} \mathrm{C})^{3}, 128.4$ $\left(\mathrm{CH}, \mathrm{C}^{6}\right), 129.7\left(\mathrm{CH}, \mathrm{C}^{5}\right), 130.6\left(\mathrm{C}, \mathrm{J}_{\mathrm{PtC}}=22 \mathrm{~Hz}, \mathrm{C}^{10}\right), 136.2\left(\mathrm{CH}, \mathrm{C}^{7}\right)$, $137.1\left(\mathrm{C}, \mathrm{J}_{\mathrm{PtC}}=32 \mathrm{~Hz} \mathrm{C}^{8}\right), 137.9\left(\mathrm{CH}, \mathrm{C}^{4}\right), 147.7\left(\mathrm{C}, \mathrm{C}^{9}\right), 156.0(\mathrm{CH}$, $\left.\mathrm{J}_{\mathrm{PtC}}=43 \mathrm{~Hz}, \mathrm{C}^{2}\right), 174.3\left(\mathrm{C}, \mathrm{J}_{\mathrm{PtC}}=60 \mathrm{~Hz}, \mathrm{CO}\right), 176.4\left(\mathrm{C}, \mathrm{J}_{\mathrm{PtC}}=60 \mathrm{~Hz}\right.$, $\mathrm{CO})$.

IR, $\mathrm{KBr}$ pellets $\left(\mathrm{cm}^{-1}\right): v_{\mathrm{C}=\mathrm{O}}=1686$.

Elemental anal. (\%) for $\mathrm{C}_{16} \mathrm{H}_{17} \mathrm{NO}_{4}$ PtS: C 37.35, H 3.33, N 2.72. Found: C 37.42, H 3.27, N 2.87.

\subsubsection{Synthesis of complex 1c}

Reaction time: $60 \mathrm{~min}$. Temperature: $45^{\circ} \mathrm{C}$. Yield $49 \%$. Color: pale brown.

${ }^{1} \mathbf{H}-\mathrm{NMR}$ (300 MHz, $\left.\mathbf{C D}_{\mathbf{2}} \mathbf{C l}_{\mathbf{2}}, \mathbf{T}=\mathbf{2 9 8} \mathbf{K}, \mathbf{p p m}\right) \delta: 3.00(\mathrm{~s}$, $\left.\mathrm{J}_{\mathrm{PtH}}=51.0 \mathrm{~Hz}, 3 \mathrm{H}, \mathrm{SCH}_{3}\right), 3.68\left(\mathrm{~d}, 1 \mathrm{H}, \mathrm{J}=3.7 \mathrm{~Hz}, \mathrm{~J}_{\mathrm{PtH}}=83.6 \mathrm{~Hz}\right.$, $\mathrm{CH}=\mathrm{CH}), 3.98\left(\mathrm{~d}, 1 \mathrm{H}, \mathrm{J}=3.7 \mathrm{~Hz}, \mathrm{~J}_{\mathrm{PtH}}=82.1 \mathrm{~Hz}, \mathrm{CH}=\mathrm{CH}\right), 7.66(\mathrm{dd}$, $\left.1 \mathrm{H}, \mathrm{J}=8.4,4.9 \mathrm{~Hz}, \mathrm{H}^{3}\right), 7.79\left(\mathrm{dd}, 1 \mathrm{H}, \mathrm{J}=8.2,7.3 \mathrm{~Hz}, \mathrm{H}^{6}\right), 8.00(\mathrm{dd}$, $\left.1 \mathrm{H}, \mathrm{J}=8.2,1.2 \mathrm{~Hz}, \mathrm{H}^{5}\right), 8.20\left(\mathrm{dd}, 1 \mathrm{H}, \mathrm{J}=7.3,1.2 \mathrm{~Hz}, \mathrm{H}^{7}\right), 8.63(\mathrm{dd}$, $\left.1 \mathrm{H}, \mathrm{J}=8.4,1.5 \mathrm{~Hz}, \mathrm{H}^{4}\right), 9.68\left(\mathrm{dd}, 1 \mathrm{H}, \mathrm{J}=4.9,1.5 \mathrm{~Hz}, \mathrm{JPtH}_{\mathrm{PtH}}=36.4 \mathrm{~Hz}\right.$, $\left.\mathrm{H}^{2}\right)$.

${ }^{13} \mathbf{C}\left\{{ }^{1} \mathbf{H}\right\}-N M R\left(\mathbf{C D}_{\mathbf{2}} \mathbf{C l}_{\mathbf{2}}, \mathbf{T}=\mathbf{2 5 3} \mathbf{K}, \mathbf{p p m}\right) \delta: 28.7\left(\mathrm{CH}_{3}, \mathrm{SCH}_{3}\right), 29.3$ (bs, $\mathrm{CH}, \mathrm{CH}=\mathrm{CH}), 34.3(\mathrm{bs}, \mathrm{CH}=\mathrm{CH}), 124.1\left(\mathrm{CH}, \mathrm{J}_{\mathrm{PtC}}=42 \mathrm{~Hz} \mathrm{C}^{3}\right)$, $128.9\left(\mathrm{CH}, \mathrm{C}^{6}\right), 130.4\left(\mathrm{CH}, \mathrm{C}^{5}\right), 130.5\left(\mathrm{C}, \mathrm{J}_{\mathrm{PtC}}=26 \mathrm{~Hz}, \mathrm{C}^{10}\right), 136.0$ $\left(\mathrm{C}, \mathrm{JPtC}_{\mathrm{PtC}}=32 \mathrm{~Hz} \mathrm{C}^{8}\right), 136.9\left(\mathrm{CH}, \mathrm{C}^{7}\right), 139.0\left(\mathrm{CH}, \mathrm{C}^{4}\right), 147.6\left(\mathrm{C}, \mathrm{C}^{9}\right)$, 157.4 (CH, JPtC $\left.=44 \mathrm{~Hz}, \mathrm{C}^{2}\right), 173.1(\mathrm{C}, \mathrm{CO}), 173.5(\mathrm{C}, \mathrm{CO})$.

IR, $\mathrm{KBr}$ pellets $\left(\mathrm{cm}^{-1}\right): v_{\mathrm{C}=\mathrm{O}}=1795,1723$.

Elemental anal. (\%) for $\mathrm{C}_{14} \mathrm{H}_{11} \mathrm{NO}_{3}$ PtS: C 35.90, H 2.37, N 2.99. Found: C 36.08, H 2.21, N 2.87.

\subsubsection{Synthesis of complex $\mathbf{1 d}$}

Reaction time: $60 \mathrm{~min}$. Temperature: $45^{\circ} \mathrm{C}$. Yield $48 \%$. Color: greenish.

${ }^{1} \mathbf{H}-N M R$ (300 MHz, $\left.\mathbf{C D}_{\mathbf{2}} \mathbf{C l}_{2}, \mathbf{T}=\mathbf{2 9 8} \mathbf{K}, \mathbf{p p m}\right) \delta$ : $2.82(\mathrm{~s}$, $\left.\mathrm{J}_{\mathrm{PtH}}=51.2 \mathrm{~Hz}, 3 \mathrm{H}, \mathrm{SCH}_{3}\right), 4.44\left(\mathrm{~d}, 1 \mathrm{H}, \mathrm{J}=6.3 \mathrm{~Hz}, \mathrm{~J}_{\mathrm{PtH}}=75.6 \mathrm{~Hz}\right.$, $\mathrm{CH}=\mathrm{CH}), 4.68\left(\mathrm{~d}, 1 \mathrm{H}, \mathrm{J}=6.3 \mathrm{~Hz}, \mathrm{~J}_{\mathrm{PtH}}=71.4 \mathrm{~Hz}, \mathrm{CH}=\mathrm{CH}\right), 7.43-$ $7.52\left(\mathrm{~m}, 2 \mathrm{H}\right.$, aryl-nq), 7.76-7.74 $\left(\mathrm{m}, 2 \mathrm{H}, \mathrm{H}^{3}, \mathrm{H}^{6}\right), 7.93(\mathrm{dd}, 1 \mathrm{H}$, $\left.\mathrm{J}=8.2,1.2 \mathrm{~Hz}, \mathrm{H}^{5}\right), 7.99-8.04(\mathrm{~m}, 2 \mathrm{H}$, aryl-nq), $8.13(\mathrm{dd}, 1 \mathrm{H}$, $\left.\mathrm{J}=7.3,1.2 \mathrm{~Hz}, \mathrm{H}^{7}\right), 8.54\left(\mathrm{dd}, 1 \mathrm{H}, \mathrm{J}=8.4,1.5 \mathrm{~Hz}, \mathrm{H}^{4}\right), 9.32(\mathrm{dd}, 1 \mathrm{H}$, $\left.\mathrm{J}=4.9,1.5 \mathrm{~Hz}, \mathrm{~J}_{\mathrm{PtH}}=35.7 \mathrm{~Hz}, \mathrm{H}^{2}\right)$.

${ }^{13} \mathbf{C}\left\{{ }^{1} \mathbf{H}\right\}-N M R\left(\mathbf{C D}_{\mathbf{2}} \mathbf{C l}_{\mathbf{2}}, \mathbf{T}=\mathbf{2 9 8} \mathbf{K}, \mathbf{p p m}\right) \delta: 28.2\left(\mathrm{CH}_{3}, \mathrm{SCH}_{3}\right), 44.5$ $\left(\mathrm{CH}, \mathrm{J}_{\mathrm{PtC}}=320 \mathrm{~Hz} \mathrm{CH}=\mathrm{CH}\right), 52.0\left(\mathrm{CH}, \mathrm{J}_{\mathrm{PtC}}=287 \mathrm{~Hz}, \mathrm{CH}=\mathrm{CH}\right), 124.0$ $\left(\mathrm{CH}, \mathrm{J}_{\mathrm{PtC}}=40 \mathrm{~Hz} \mathrm{C}^{3}\right), 125.0(\mathrm{CH}$, aryl-nq), $125.2(\mathrm{CH}$, aryl-nq), 128.6 $\left(\mathrm{CH}, \mathrm{C}^{6}\right), 130.0\left(\mathrm{CH}\right.$, aryl-nq), $130.6\left(\mathrm{C}, \mathrm{C}^{10}\right), 131.0(\mathrm{CH}$, aryl-nq), $131.1\left(\mathrm{CH}, \mathrm{C}^{5}\right), 136.0\left(\mathrm{C}\right.$, aryl-nq), $136.2\left(\mathrm{CH}, \mathrm{C}^{7}\right), 136.6\left(\mathrm{C}, \mathrm{C}^{8}\right)$, $136.7\left(\mathrm{C}\right.$, aryl-nq), $138.4\left(\mathrm{CH}, \mathrm{C}^{4}\right), 148.0\left(\mathrm{C}, \mathrm{C}^{9}\right), 153.9\left(\mathrm{CH}, \mathrm{J}_{\mathrm{PtC}}=\right.$ $32 \mathrm{~Hz}, \mathrm{C}^{2}$ ), 184.8 (C, CO), 188.7 (C, CO).

IR, $\mathrm{KBr}$ pellets $\left(\mathrm{cm}^{-1}\right): v_{\mathrm{C}=\mathrm{O}}=1622,1583$.

Elemental anal. (\%) for $\mathrm{C}_{34} \mathrm{H}_{27} \mathrm{~N}_{3} \mathrm{O}_{9}$ PtS: C 45.45, H 2.86, N 2.65 . Found: C 45.31, H 2.98, N 2.72 .

\subsubsection{Synthesis of complex $\mathbf{2 a}$}

Reaction time: $60 \mathrm{~min}$. Temperature: $45^{\circ} \mathrm{C}$. Yield 54\%. Color: yellow.

${ }^{\mathbf{1}} \mathbf{H}-\mathrm{NMR}$ (300 MHz, $\left.\mathbf{C D C l}_{\mathbf{3}}, \mathbf{T}=\mathbf{2 9 8} \mathbf{K}, \mathbf{p p m}\right) \delta: 1.42\left(\mathrm{~s}, 9 \mathrm{H},{ }^{t} \mathrm{Bu}\right)$, $3.64\left(\mathrm{~s}, 6 \mathrm{H}, \mathrm{OCH}_{3}\right), 3.66\left(\mathrm{~s}, 6 \mathrm{H}, \mathrm{OCH}_{3}\right), 3.73(\mathrm{~d}, 1 \mathrm{H}, \mathrm{J}=8.7 \mathrm{~Hz}$, $\left.\mathrm{J}_{\mathrm{PtH}}=91.0 \mathrm{~Hz}, \mathrm{CH}=\mathrm{CH}\right), 3.94\left(\mathrm{~d}, 1 \mathrm{H}, \mathrm{J}=8.7 \mathrm{~Hz}, \mathrm{~J}_{\mathrm{PtH}}=88.2 \mathrm{~Hz}\right.$, $\mathrm{CH}=\mathrm{CH}), 7.55\left(\mathrm{dd}, 1 \mathrm{H}, \mathrm{J}=8.3,4.9 \mathrm{~Hz}, \mathrm{H}^{3}\right), 7.68(\mathrm{dd}, 1 \mathrm{H}, \mathrm{J}=8.2$, $\left.7.3 \mathrm{~Hz}, \mathrm{H}^{6}\right), 7.94\left(\mathrm{dd}, 1 \mathrm{H}, \mathrm{J}=8.2,1.2 \mathrm{~Hz}, \mathrm{H}^{5}\right), 8.11(\mathrm{dd}, 1 \mathrm{H}, \mathrm{J}=7.3$,
$1.2 \mathrm{~Hz}, \mathrm{H}^{7}$ ), $8.52\left(\mathrm{dd}, 1 \mathrm{H}, \mathrm{J}=8.3,1.5 \mathrm{~Hz}, \mathrm{H}^{4}\right), 9.74(\mathrm{dd}, 1 \mathrm{H}, \mathrm{J}=4.9$, $\left.1.5 \mathrm{~Hz}, \mathrm{~J}_{\mathrm{PtH}}=35.0 \mathrm{~Hz}, \mathrm{H}^{2}\right)$.

${ }^{13} \mathbf{C}\left\{{ }^{1} \mathbf{H}\right\}-N M R\left(\mathbf{C D C l}_{\mathbf{3}}, \mathbf{T}=\mathbf{2 9 8} \mathbf{K}, \mathbf{p p m}\right) \delta: 29.1\left(\mathrm{CH}, \mathrm{J}_{\mathrm{PtC}}=377 \mathrm{~Hz}\right.$ $\mathrm{CH}=\mathrm{CH}), 30.5\left(\mathrm{CH}_{3}, \mathrm{JPtC}_{\mathrm{PtC}}=19 \mathrm{~Hz}, \mathrm{CMe}_{3}\right), 35.6\left(\mathrm{CH}, \mathrm{JPtC}_{\mathrm{PtC}}=346 \mathrm{~Hz}\right.$ $\mathrm{CH}=\mathrm{CH}), 50.8\left(\mathrm{CH}_{3}, \mathrm{OCH}_{3}\right), 50.9\left(\mathrm{CH}_{3}, \mathrm{OCH}_{3}\right), 56.7\left(\mathrm{C}, \mathrm{CMe}_{3}\right)$, $123.6\left(\mathrm{CH}, \mathrm{JPtC}_{\mathrm{PtC}}=40 \mathrm{~Hz} \mathrm{C}^{3}\right), 127.7\left(\mathrm{CH}, \mathrm{C}^{6}\right), 130.3\left(\mathrm{CH}, \mathrm{C}^{5}\right), 130.6$ $\left(\mathrm{C}, \mathrm{J}_{\mathrm{PtC}}=23 \mathrm{~Hz}, \mathrm{C}^{10}\right), 134.1\left(\mathrm{C}, \mathrm{JPtC}_{\mathrm{PtC}}=33 \mathrm{~Hz} \mathrm{C}^{8}\right), 137.4\left(\mathrm{CH}, \mathrm{C}^{4}\right)$, $138.1\left(\mathrm{CH}, \mathrm{C}^{7}\right), 147.7\left(\mathrm{C}, \mathrm{C}^{9}\right), 155.7\left(\mathrm{CH}, \mathrm{J}_{\mathrm{PtC}}=44 \mathrm{~Hz}, \mathrm{C}^{2}\right), 174.9(\mathrm{C}$, $\left.\mathrm{J}_{\mathrm{PtC}}=60 \mathrm{~Hz}, \mathrm{CO}\right), 176.9\left(\mathrm{C}, \mathrm{J}_{\mathrm{PtC}}=60 \mathrm{~Hz}, \mathrm{CO}\right)$.

IR, $\mathrm{KBr}$ pellets $\left(\mathrm{cm}^{-1}\right): v_{\mathrm{C}=\mathrm{O}}=1697,1686$.

Elemental anal. (\%) for $\mathrm{C}_{19} \mathrm{H}_{23} \mathrm{NO}_{4}$ PtS: C 41.00, H 4.17, N 2.52 . Found: C 40.92, H 4.21, N 2.70.

\subsubsection{Synthesis of complex $\mathbf{2 b}$}

Reaction time: $60 \mathrm{~min}$. Temperature: $45^{\circ} \mathrm{C}$. Yield 61\%. Color: pale brown.

${ }^{1} \mathbf{H}-\mathrm{NMR}\left(300 \mathbf{~ M H z}, \mathbf{C D C l}_{\mathbf{3}}, \mathbf{T}=\mathbf{2 9 8} \mathbf{K}, \mathbf{p p m}\right) \delta: 1.49\left(\mathrm{~s}, 9 \mathrm{H},{ }^{t} \mathrm{Bu}\right)$, $2.79\left(\mathrm{~d}, 1 \mathrm{H}, \mathrm{J}=7.9 \mathrm{~Hz}, \mathrm{~J}_{\mathrm{PtH}}=87.3 \mathrm{~Hz}, \mathrm{CH}=\mathrm{CH}\right), 3.12(\mathrm{~d}, 1 \mathrm{H}$ $\left.\mathrm{J}=7.9 \mathrm{~Hz}, \mathrm{~J}_{\mathrm{PtH}}=88.2 \mathrm{~Hz}, \mathrm{CH}=\mathrm{CH}\right), 7.63(\mathrm{dd}, 1 \mathrm{H}, \mathrm{J}=8.4,4.9 \mathrm{~Hz}$, $\left.\mathrm{H}^{3}\right), 7.76\left(\mathrm{dd}, 1 \mathrm{H}, \mathrm{J}=8.2,7.3 \mathrm{~Hz}, \mathrm{H}^{6}\right), 8.02(\mathrm{dd}, 1 \mathrm{H}, \mathrm{J}=8.2,1.2 \mathrm{~Hz}$, $\left.\mathrm{H}^{5}\right), 8.16\left(\mathrm{dd}, 1 \mathrm{H}, \mathrm{J}=7.3,1.3 \mathrm{~Hz}, \mathrm{H}^{7}\right), 8.60(\mathrm{dd}, 1 \mathrm{H}, \mathrm{J}=8.4,1.6 \mathrm{~Hz}$, $\left.\mathrm{H}^{4}\right), 9.71\left(\mathrm{dd}, 1 \mathrm{H}, \mathrm{J}=4.9,1.6 \mathrm{~Hz}, \mathrm{JPtH}=32.7 \mathrm{~Hz}, \mathrm{H}^{2}\right)$.

${ }^{13} \mathbf{C}\left\{{ }^{1} \mathbf{H}\right\}-N M R\left(\mathbf{C D C l}_{\mathbf{3}}, \mathbf{T}=\mathbf{2 9 8} \mathbf{K}, \mathbf{p p m}\right) \delta: 4.8\left(\mathrm{CH}, \mathrm{J}_{\mathrm{PtC}}=426 \mathrm{~Hz}\right.$ $\mathrm{CH}=\mathrm{CH}), 9.8\left(\mathrm{CH}, \mathrm{J}_{\mathrm{PtC}}=416 \mathrm{~Hz}, \mathrm{CH}=\mathrm{CH}\right), 30.6\left(\mathrm{CH}_{3}, \mathrm{~J}_{\mathrm{PtC}}=20 \mathrm{~Hz}\right.$ $\left.\mathrm{CMe}_{3}\right), 58.0\left(\mathrm{C}, \mathrm{CMe}_{3}\right), 123.5(\mathrm{C}, \mathrm{CN}), 123.8\left(\mathrm{CH}, \mathrm{JPtC}=41 \mathrm{~Hz}, \mathrm{C}^{3}\right)$, $124.1(\mathrm{C}, \mathrm{CN}), 128.2\left(\mathrm{CH}, \mathrm{C}^{6}\right), 130.7\left(\mathrm{C}, \mathrm{JPtC}_{\mathrm{PtC}}=27 \mathrm{~Hz}, \mathrm{C}^{10}\right), 130.8$ $\left(\mathrm{CH}, \mathrm{C}^{5}\right), 133.1\left(\mathrm{C}, \mathrm{J}_{\mathrm{PtC}}=31 \mathrm{~Hz}, \mathrm{C}^{8}\right), 138.4\left(\mathrm{CH}, \mathrm{C}^{7}\right), 138.5\left(\mathrm{CH}, \mathrm{C}^{4}\right)$, $149.5\left(\mathrm{C}, \mathrm{C}^{9}\right), 157.1\left(\mathrm{CH}, \mathrm{JPtC}_{\mathrm{C}}=47 \mathrm{~Hz}, \mathrm{C}^{2}\right)$.

IR, $\mathrm{KBr}$ pellets $\left(\mathrm{cm}^{-1}\right): v_{\mathrm{CN}}=2201$.

Elemental anal. (\%) for $\mathrm{C}_{17} \mathrm{H}_{17} \mathrm{~N}_{3}$ PtS: C 41.63, H 3.49, N 8.57. Found: C 41.78, H 3.54, N 8.49.

\subsubsection{Synthesis of complex $\mathbf{2 c}$}

Reaction time: $60 \mathrm{~min}$. Temperature: $45^{\circ} \mathrm{C}$. Yield 57\%. Color: greenish.

${ }^{1} \mathbf{H}-\mathrm{NMR}$ (300 MHz, $\left.\mathbf{C D C l}_{\mathbf{3}}, \mathbf{T}=\mathbf{2 9 8} \mathbf{K}, \mathbf{p p m}\right) \delta$ : $1.44\left(\mathrm{~s}, 9 \mathrm{H},{ }^{t} \mathrm{Bu}\right)$, $3.66\left(\mathrm{~d}, 1 \mathrm{H}, \mathrm{J}=3.7 \mathrm{~Hz}, \mathrm{~J}_{\mathrm{PtH}}=83.4 \mathrm{~Hz}, \mathrm{CH}=\mathrm{CH}\right), 4.01(\mathrm{~d}, 1 \mathrm{H}$, $\left.\mathrm{J}=3.7 \mathrm{~Hz}, \mathrm{~J}_{\mathrm{PtH}}=82.7 \mathrm{~Hz}, \mathrm{CH}=\mathrm{CH}\right), 7.60(\mathrm{dd}, 1 \mathrm{H}, \mathrm{J}=8.4,4.9 \mathrm{~Hz}$, $\left.\mathrm{H}^{3}\right), 7.74\left(\mathrm{dd}, 1 \mathrm{H}, \mathrm{J}=8.2,7.3 \mathrm{~Hz}, \mathrm{H}^{6}\right), 8.00(\mathrm{dd}, 1 \mathrm{H}, \mathrm{J}=8.2,1.2 \mathrm{~Hz}$, $\left.\mathrm{H}^{5}\right), 8.13\left(\mathrm{dd}, 1 \mathrm{H}, \mathrm{J}=7.3,1.2 \mathrm{~Hz}, \mathrm{H}^{7}\right), 8.57(\mathrm{dd}, 1 \mathrm{H}, \mathrm{J}=8.4,1.5 \mathrm{~Hz}$, $\left.\mathrm{H}^{4}\right), 9.65\left(\mathrm{dd}, 1 \mathrm{H}, \mathrm{J}=4.9,1.5 \mathrm{~Hz}, \mathrm{JPtH}_{\mathrm{PtH}}=36.4 \mathrm{~Hz}, \mathrm{H}^{2}\right)$.

${ }^{13} \mathbf{C}\left\{{ }^{1} \mathbf{H}\right\}-N M R\left(\mathbf{C D}_{\mathbf{2}} \mathbf{C l}_{2}, \mathbf{T}=\mathbf{2 7 3} \mathbf{K}, \mathbf{p p m}\right) \delta: 29.2$ (bs, $\mathrm{CH}$ $\mathrm{CH}=\mathrm{CH}), 30.2\left(\mathrm{bs}, \mathrm{CH}_{3}, \mathrm{CMe}_{3}\right), 34.3\left(\mathrm{CH}, \mathrm{J}_{\mathrm{PtH}}=354 \mathrm{~Hz}, \mathrm{CH}=\mathrm{CH}\right)$, $\left.58.3\left(\mathrm{C}, \mathrm{CMe}_{3}\right), 124.0\left(\mathrm{CH}, \mathrm{JPtC}_{\mathrm{PtC}}=42 \mathrm{~Hz} \mathrm{C}\right)^{3}\right), 128.2\left(\mathrm{CH}, \mathrm{C}^{6}\right), 130.6$ $\left(\mathrm{C}, \mathrm{J}_{\mathrm{PtC}}=27 \mathrm{~Hz}, \mathrm{C}^{10}\right), 130.9\left(\mathrm{CH}, \mathrm{C}^{5}\right), 132.6\left(\mathrm{C}, \mathrm{J}_{\mathrm{PtC}}=31 \mathrm{~Hz} \mathrm{C}^{8}\right)$, 138.6 (CH, C $\left.{ }^{7}\right), 138.7\left(\mathrm{CH}, \mathrm{C}^{4}\right), 149.3\left(\mathrm{C}, \mathrm{C}^{9}\right), 156.9$ (bs, $\left.\mathrm{CH}, \mathrm{C}^{2}\right)$, $173.3(\mathrm{C}, \mathrm{CO}), 174.9(\mathrm{C}, \mathrm{CO})$.

IR, $\mathrm{KBr}$ pellets $\left(\mathrm{cm}^{-1}\right): v_{\mathrm{C}=\mathrm{O}}=1798,1728$.

Elemental anal. (\%) for $\mathrm{C}_{17} \mathrm{H}_{17} \mathrm{NO}_{3}$ PtS: C 40.00, H 3.36, N 2.74. Found: C 40.13, H 3.41, N 2.58 .

\subsubsection{Synthesis of complex $\mathbf{2 d}$}

Reaction time: $60 \mathrm{~min}$. Temperature: $45^{\circ} \mathrm{C}$. Yield 53\%. Color: greenish.

${ }^{1} \mathbf{H}$-NMR (300 MHz, $\left.\mathbf{C D C l}_{\mathbf{3}}, \mathbf{T}=\mathbf{2 9 8} \mathbf{K}, \mathbf{p p m}\right) \delta: 1.21\left(\mathrm{~s}, 9 \mathrm{H},{ }^{t} \mathrm{Bu}\right)$, $4.49\left(\mathrm{~d}, 1 \mathrm{H}, \mathrm{J}=6.4 \mathrm{~Hz}, \mathrm{~J}_{\mathrm{PtH}}=73.4 \mathrm{~Hz}, \mathrm{CH}=\mathrm{CH}\right), 4.70(\mathrm{~d}, 1 \mathrm{H}$, $\left.\mathrm{J}=6.4 \mathrm{~Hz}, \mathrm{~J}_{\mathrm{PtH}}=70.3 \mathrm{~Hz}, \mathrm{CH}=\mathrm{CH}\right), 7.44-7.53(\mathrm{~m}, 2 \mathrm{H}$, aryl-nq), 7.64-7.69 (m, 2H, H $\left.{ }^{3}, \mathrm{H}^{6}\right), 7.93\left(\mathrm{dd}, 1 \mathrm{H}, \mathrm{J}=8.2,1.2 \mathrm{~Hz}, \mathrm{H}^{5}\right), 7.91-$ $7.94\left(\mathrm{~m}, 3 \mathrm{H}\right.$, aryl-nq, $\left.\mathrm{H}^{7}\right), 8.48\left(\mathrm{dd}, 1 \mathrm{H}, \mathrm{J}=8.4,1.5 \mathrm{~Hz}, \mathrm{H}^{4}\right), 9.37$ $\left(\mathrm{dd}, 1 \mathrm{H}, \mathrm{J}=4.9,1.5 \mathrm{~Hz}, \mathrm{~J}_{\mathrm{PtH}}=36.4 \mathrm{~Hz}, \mathrm{H}^{2}\right.$ ).

${ }^{13} \mathbf{C}\left\{{ }^{1} \mathbf{H}\right\}-N M R\left(\mathbf{C D C l}_{3}, \mathbf{T}=\mathbf{2 9 8} \mathbf{K}, \mathbf{p p m}\right) \delta: 30.1\left(\mathrm{CH}_{3}, \mathrm{CMe}_{3}\right), 44.7$ $\left(\mathrm{CH}, \mathrm{JPtC}_{\mathrm{Pt}}=342 \mathrm{~Hz} \mathrm{CH}=\mathrm{CH}\right), 52.9\left(\mathrm{CH}, \mathrm{J}_{\mathrm{PtC}}=276 \mathrm{~Hz}, \mathrm{CH}=\mathrm{CH}\right), 124.0$ $\left(\mathrm{CH}, \mathrm{J}_{\mathrm{PtC}}=39 \mathrm{~Hz}, \mathrm{C}^{3}\right), 125.3(\mathrm{CH}$, aryl-nq), $125.8(\mathrm{CH}$, aryl-nq), 127.9 $\left(\mathrm{CH}, \mathrm{C}^{6}\right), 130.4\left(\mathrm{C}, \mathrm{C}^{10}\right), 130.5\left(\mathrm{CH}, \mathrm{C}^{5}\right), 131.0(\mathrm{CH}$, aryl-nq), 131.4 ( $\mathrm{CH}$, aryl-nq), $133.0\left(\mathrm{C}, \mathrm{J}_{\mathrm{PtC}}=32 \mathrm{~Hz}, \mathrm{C}^{8}\right), 136.5$ (C, aryl-nq), 136.9 
(C, aryl-nq), $137.9\left(\mathrm{CH}, \mathrm{C}^{7}\right), 138.0\left(\mathrm{CH}, \mathrm{C}^{4}\right), 149.9\left(\mathrm{C}, \mathrm{C}^{9}\right), 152.9(\mathrm{CH}$, $\left.\mathrm{J}_{\mathrm{PtC}}=28 \mathrm{~Hz}, \mathrm{C}^{2}\right), 184.3(\mathrm{C}, \mathrm{CO}), 190.5(\mathrm{C}, \mathrm{CO})$.

IR, $\mathrm{KBr}$ pellets $\left(\mathrm{cm}^{-1}\right): v_{\mathrm{C}}={ }_{\mathrm{O}}=1639,1616$.

Elemental anal. (\%) for $\mathrm{C}_{23} \mathrm{H}_{21} \mathrm{NO}_{2}$ PtS: C 48.42, H 3.71, N 2.45 . Found: C 48.37, H 3.58, N 2.41.

\subsubsection{Synthesis of complex $3 \boldsymbol{a}$}

Reaction time: $60 \mathrm{~min}$. Temperature: $45^{\circ} \mathrm{C}$. Yield 53\%. Color: yellow.

${ }^{1} \mathbf{H}-N M R\left(300 \mathbf{M H z}, \mathbf{C D}_{\mathbf{2}} \mathbf{C l}_{\mathbf{2}}, \mathbf{T}=\mathbf{2 9 8} \mathbf{K}, \mathbf{p p m}\right) \delta: 2.92(\mathrm{~s}$, $\left.\mathrm{J}_{\mathrm{PtH}}=52.1 \mathrm{~Hz}, 3 \mathrm{H}, \mathrm{SCH}_{3}\right), 3.15\left(\mathrm{~s}, 3 \mathrm{H}, \mathrm{J}_{\mathrm{PtH}}=8.5 \mathrm{~Hz}, \mathrm{CH}_{3}\right.$-quinoline $)$, $3.46\left(\mathrm{~d}, 1 \mathrm{H}, \mathrm{J}=8.4 \mathrm{~Hz}, \mathrm{JPtH}_{\mathrm{Pt}}=88.4 \mathrm{~Hz}, \mathrm{CH}=\mathrm{CH}\right), 3.61\left(\mathrm{~s}, 6 \mathrm{H}, \mathrm{OCH}_{3}\right)$, $3.62\left(\mathrm{~s}, 6 \mathrm{H}, \mathrm{OCH}_{3}\right), 3.84\left(\mathrm{~d}, 1 \mathrm{H}, \mathrm{J}=8.4 \mathrm{~Hz}, \mathrm{~J}_{\mathrm{PtH}}=85.2 \mathrm{~Hz}, \mathrm{CH}=\mathrm{CH}\right)$, 7.63-7.70 (m, 2H, $\left.\mathrm{H}^{3}, \mathrm{H}^{6}\right), 7.89\left(\mathrm{dd}, 1 \mathrm{H}, \mathrm{J}=8.0,1.3 \mathrm{~Hz}, \mathrm{H}^{5}\right), 8.09$ $\left(\mathrm{dd}, 1 \mathrm{H}, \mathrm{J}=7.3,1.3 \mathrm{~Hz}, \mathrm{H}^{7}\right), 8.39\left(\mathrm{~d}, 1 \mathrm{H}, \mathrm{J}=8.4, \mathrm{H}^{4}\right)$.

${ }^{13} \mathbf{C}\left\{{ }^{1} \mathbf{H}\right\}-N M R\left(\mathbf{C D}_{2} \mathbf{C l}_{2}, \mathbf{T}=\mathbf{2 9 8} \mathbf{K}, \mathbf{p p m}\right) \delta: 28.0\left(\mathrm{CH}_{3}, \mathrm{SCH}_{3}\right), 28.5$ $\left(\mathrm{CH}, \mathrm{J}_{\mathrm{PtC}}=349 \mathrm{~Hz} \mathrm{CH}=\mathrm{CH}\right), 32.8\left(\mathrm{CH}_{3}, \mathrm{~J}_{\mathrm{PtC}}=28 \mathrm{~Hz}, \mathrm{CH}_{3}\right.$-quinoline $)$, $34.3\left(\mathrm{CH}, \mathrm{J}_{\mathrm{PtC}}=404 \mathrm{~Hz}, \mathrm{CH}=\mathrm{CH}\right), 50.5\left(\mathrm{CH}_{3}, \mathrm{OCH}_{3}\right), 50.7\left(\mathrm{CH}_{3}\right.$, $\left.\mathrm{OCH}_{3}\right), 124.0\left(\mathrm{CH}, \mathrm{J}_{\mathrm{PtC}}=27 \mathrm{~Hz} \mathrm{C}^{3}\right), 126.9\left(\mathrm{CH}, \mathrm{C}^{6}\right), 128.8(\mathrm{C}$, $\left.\mathrm{J}_{\mathrm{PtC}}=27 \mathrm{~Hz}, \mathrm{C}^{10}\right), 129.6\left(\mathrm{CH}, \mathrm{C}^{5}\right), 135.7\left(\mathrm{CH}, \mathrm{C}^{7}\right), 136.3\left(\mathrm{C}, \mathrm{J}_{\mathrm{PtC}}=23\right.$, $\left.\mathrm{Hz} \mathrm{C}^{8}\right), 138.0\left(\mathrm{CH}, \mathrm{C}^{4}\right), 148.4\left(\mathrm{C}, \mathrm{C}^{9}\right), 165.4\left(\mathrm{CH}, \mathrm{JPtC}_{\mathrm{PtC}}=38 \mathrm{~Hz}, \mathrm{C}^{2}\right)$, $175.4\left(\mathrm{C}, \mathrm{J}_{\mathrm{PtC}}=58 \mathrm{~Hz}, \mathrm{CO}\right), 175.5\left(\mathrm{C}, \mathrm{J}_{\mathrm{PtC}}=55 \mathrm{~Hz}, \mathrm{CO}\right)$.

IR, $\mathrm{KBr}$ pellets $\left(\mathrm{cm}^{-1}\right): v_{\mathrm{C}=\mathrm{O}}=1686$.

Elemental anal. (\%) for $\mathrm{C}_{17} \mathrm{H}_{19} \mathrm{NO}_{4} \mathrm{PtS}$ : C 38.64, H 3.62, N 2.65. Found: C 38.49, H 3.51, N 2.48.

\subsubsection{Synthesis of complex $\mathbf{3 b}$}

Reaction time: $60 \mathrm{~min}$. Temperature: $45^{\circ} \mathrm{C}$. Yield 52\%. Color: pale-brown.

${ }^{1} \mathbf{H}-\mathrm{NMR}\left(300 \mathbf{M H z}, \mathbf{C D C l}_{\mathbf{3}}, \mathbf{T}=\mathbf{2 9 8} \mathbf{K}, \mathbf{p p m}\right) \delta: 2.86(\mathrm{~d}, 1 \mathrm{H}$, $\left.\mathrm{J}=7.8 \mathrm{~Hz}, \mathrm{~J}_{\mathrm{PtH}}=87.7 \mathrm{~Hz}, \mathrm{CH}=\mathrm{CH}\right), 3.02\left(\mathrm{~s}, \mathrm{~J}_{\mathrm{PtH}}=50.2 \mathrm{~Hz}, 3 \mathrm{H}\right.$, $\left.\mathrm{SCH}_{3}\right), 3.03\left(\mathrm{~d}, 1 \mathrm{H}, \mathrm{J}=7.8 \mathrm{~Hz}, \mathrm{~J}_{\mathrm{PtH}}=86.7 \mathrm{~Hz}, \mathrm{CH}=\mathrm{CH}\right), 3.29(\mathrm{~s}, 3 \mathrm{H}$, $\mathrm{J}_{\mathrm{PtH}}=8.0 \mathrm{~Hz}, \mathrm{CH}_{3}$-quinoline), 7.68-7.75 (m, 2H, $\left.\mathrm{H}^{3}, \mathrm{H}^{6}\right), 7.93(\mathrm{dd}$, $\left.1 \mathrm{H}, \mathrm{J}=8.1,1.2 \mathrm{~Hz}, \mathrm{H}^{5}\right), 8.13\left(\mathrm{dd}, 1 \mathrm{H}, \mathrm{J}=7.3,1.2 \mathrm{~Hz}, \mathrm{H}^{7}\right), 8.42(\mathrm{~d}$, $\left.1 \mathrm{H}, \mathrm{J}=8.4 \mathrm{~Hz}, \mathrm{H}^{4}\right)$.

${ }^{13} \mathbf{C}\left\{{ }^{1} \mathbf{H}\right\}-N M R\left(\mathbf{C D C l}_{\mathbf{3}}, \mathbf{T}=\mathbf{2 9 8} \mathbf{K}, \mathbf{p p m}\right) \delta: 2.8(\mathrm{CH}, \mathrm{JPtC}=395 \mathrm{~Hz}$ $\mathrm{CH}=\mathrm{CH}), 10.4\left(\mathrm{CH}, \mathrm{JPtC}_{\mathrm{PC}}=410 \mathrm{~Hz}, \mathrm{CH}=\mathrm{CH}\right), 29.1\left(\mathrm{CH}_{3}, \mathrm{SCH}_{3}\right), 32.9$ $\left(\mathrm{CH}_{3}, \mathrm{CH}_{3}\right.$-quinoline), $123.4(\mathrm{C}, \mathrm{CN}), 123.9(\mathrm{C}, \mathrm{CN}), 124.5(\mathrm{CH}$, $\left.\mathrm{JPtC}_{\mathrm{PtC}}=40 \mathrm{~Hz}, \mathrm{C}^{3}\right), 127.5\left(\mathrm{CH}, \mathrm{C}^{6}\right), 128.9\left(\mathrm{C}, \mathrm{C}^{10}\right), 130.2\left(\mathrm{CH}, \mathrm{C}^{5}\right)$, $135.6\left(\mathrm{C}, \mathrm{J}_{\mathrm{PtC}}=32 \mathrm{~Hz}, \mathrm{C}^{8}\right), 136.5\left(\mathrm{CH}, \mathrm{C}^{7}\right), 138.8\left(\mathrm{CH}, \mathrm{C}^{4}\right), 148.7(\mathrm{C}$, $\left.\mathrm{C}^{9}\right), 165.5\left(\mathrm{CH}, \mathrm{C}^{2}\right)$.

IR, $\mathrm{KBr}$ pellets $\left(\mathrm{cm}^{-1}\right): v_{\mathrm{CN}}=2196$.

Elemental anal. (\%) for $\mathrm{C}_{15} \mathrm{H}_{13} \mathrm{~N}_{3}$ PtS: C 38.96, H 2.83, N 9.09. Found: C 39.07, H 2.91, N 8.92.

\subsubsection{Synthesis of complex $3 c$}

Reaction time: $60 \mathrm{~min}$. Temperature: $45^{\circ} \mathrm{C}$. Yield 50\%. Color: pale-brown.

${ }^{1} \mathrm{H}-\mathrm{NMR}$ (300 $\left.\mathbf{M H z}, \mathbf{C D C l}_{\mathbf{3}}, \mathbf{T}=\mathbf{2 9 8} \mathbf{K}, \mathbf{p p m}\right) \delta: 2.98(\mathrm{~s}$, $\left.\mathrm{JPtH}_{\mathrm{PtH}}=52.3 \mathrm{~Hz}, 3 \mathrm{H}, \mathrm{SCH}_{3}\right), 3.28\left(\mathrm{~s}, 3 \mathrm{H}, \mathrm{JPtH}_{\mathrm{PtH}}=9.3 \mathrm{~Hz}, \mathrm{CH}_{3}\right.$-quinoline $)$, $3.82\left(\mathrm{~d}, 1 \mathrm{H}, \mathrm{J}=3.8 \mathrm{~Hz}, \mathrm{~J}_{\mathrm{PtH}}=80.7 \mathrm{~Hz}, \mathrm{CH}=\mathrm{CH}\right), 3.98(\mathrm{bd}, 1 \mathrm{H}$, $\left.\mathrm{J}=3.8 \mathrm{~Hz}, \mathrm{~J}_{\mathrm{PtH}}=82.2 \mathrm{~Hz}, \mathrm{CH}=\mathrm{CH}\right), 7.65-7.71\left(\mathrm{~m}, 2 \mathrm{H}, \mathrm{H}^{3}, \mathrm{H}^{6}\right), 7.90$ (dd, $\left.1 \mathrm{H}, \mathrm{J}=8.1,1.2 \mathrm{~Hz}, \mathrm{H}^{5}\right), 8.09\left(\mathrm{dd}, 1 \mathrm{H}, \mathrm{J}=7.3,1.2 \mathrm{~Hz}, \mathrm{H}^{7}\right), 8.39$ $\left(\mathrm{d}, 1 \mathrm{H}, \mathrm{J}=8.4, \mathrm{H}^{4}\right)$.

${ }^{13} \mathbf{C}\left\{{ }^{1} \mathbf{H}\right\}-N M R\left(\mathrm{CDCl}_{\mathbf{3}}, \mathbf{T}=\mathbf{2 9 8} \mathbf{K}, \mathbf{p p m}\right) \delta: 27.1$ (bs, $\left.\mathrm{CH}, \mathrm{CH}=\mathrm{CH}\right)$, $28.8\left(\mathrm{CH}_{3}, \mathrm{SCH}_{3}\right), 32.8\left(\mathrm{CH}_{3}, \mathrm{CH}_{3}\right.$-quinoline), 34.7 (bs, $\left.\mathrm{CH}=\mathrm{CH}\right)$, $124.5\left(\mathrm{CH}, \mathrm{C}^{3}\right), 127.4\left(\mathrm{CH}, \mathrm{C}^{6}\right), 128.8\left(\mathrm{C}, \mathrm{C}^{10}\right), 130.1\left(\mathrm{CH}, \mathrm{C}^{5}\right)$, $135.8\left(\mathrm{C}, \mathrm{C}^{8}\right), 136.3\left(\mathrm{CH}, \mathrm{C}^{7}\right), 138.7\left(\mathrm{CH}, \mathrm{C}^{4}\right), 148.6\left(\mathrm{C}, \mathrm{C}^{9}\right), 165.8$ $\left(\mathrm{CH}, \mathrm{C}^{2}\right), 173.6(\mathrm{C}, \mathrm{CO}), 174.0(\mathrm{C}, \mathrm{CO})$ (incipient decomposition renders the Pt-satellites undetectable).

IR, $\mathrm{KBr}$ pellets $\left(\mathrm{cm}^{-1}\right): v_{\mathrm{C}=\mathrm{O}}=1795,1723$.

Elemental anal. (\%) for $\mathrm{C}_{15} \mathrm{H}_{13} \mathrm{NO}_{3}$ PtS: C 37.35, H 2.72, N 2.90. Found: C 37.43, H 2.65, N 2.82 .
4.6.12. Synthesis of complex $\mathbf{3 d}$

Reaction time: $60 \mathrm{~min}$. Temperature: $45^{\circ} \mathrm{C}$. Yield 50\%. Color: greenish

${ }^{1} \mathbf{H}-\mathrm{NMR}\left(300 \mathrm{MHz}, \mathbf{C D}_{\mathbf{2}} \mathbf{C l}_{2}, \mathbf{T}=\mathbf{2 9 8} \mathbf{K}, \mathbf{p p m}\right) \delta: 2.79(\mathrm{~s}, 3 \mathrm{H}$, $\left.\mathrm{J}_{\mathrm{PtH}}=51.1 \mathrm{~Hz}, \mathrm{SCH}_{3}\right), 3.18,\left(\mathrm{~s}, 3 \mathrm{H}, \mathrm{J}_{\mathrm{PtH}}=9.2 \mathrm{~Hz}\right.$ quinoline $\left.-\mathrm{CH}_{3}\right)$, $4.55,4.59$ (AB system, $2 \mathrm{H}, \mathrm{J}=6.6 \mathrm{~Hz}, \mathrm{~J}_{\mathrm{PtH}}=74.7,71.7 \mathrm{~Hz}, \mathrm{CH}=\mathrm{CH}$ ), 7.42-7.49 ( $\mathrm{m}, 2 \mathrm{H}$, aryl naphthoquinone), 7.58-7.63 $\left(\mathrm{m}, 2 \mathrm{H}, \mathrm{H}^{3}\right.$, $\left.\mathrm{H}^{6}\right), 7.83\left(\mathrm{dd}, 1 \mathrm{H}, \mathrm{J}=8.1,1.2 \mathrm{~Hz}, \mathrm{H}^{5}\right), 7.93-8.00(\mathrm{~m}, 2 \mathrm{H}$, aryl naphthoquinone), $8.02\left(\mathrm{dd}, 1 \mathrm{H}, \mathrm{J}=7.4,1.2, \mathrm{H}^{7}\right), 8.33\left(\mathrm{~d}, 1 \mathrm{H}, \mathrm{J}=8.4, \mathrm{H}^{4}\right)$.

${ }^{13} \mathbf{C}\left\{{ }^{1} \mathbf{H}\right\}-N M R\left(\mathbf{C D C l}_{\mathbf{3}}, \mathbf{T}=\mathbf{2 5 3} \mathbf{K}, \mathbf{p p m}\right) \delta: 25.2\left(\mathrm{bs}, \mathrm{CH}_{3}, \mathrm{SCH}_{3}\right)$, $30.8\left(\mathrm{CH}_{3}\right.$, quinoline- $\left.\mathrm{CH}_{3}\right), 44.0\left(\mathrm{CH}, \mathrm{J}_{\mathrm{PtC}}=305 \mathrm{~Hz}, \mathrm{CH}=\mathrm{CH}\right), 50.0$ $\left(\mathrm{CH}, \mathrm{J}_{\mathrm{PtC}}=337 \mathrm{~Hz}, \mathrm{CH}=\mathrm{CH}\right), 124.3\left(\mathrm{CH}, \mathrm{J}_{\mathrm{PtC}}=31 \mathrm{~Hz}, \mathrm{C}^{3}\right), 124.9$ ( $\mathrm{CH}$, aryl naphthoquinone), $125.3(\mathrm{CH}$, aryl naphthoquinone), $127.0\left(\mathrm{CH}, \mathrm{C}^{6}\right), 128.7\left(\mathrm{C}, \mathrm{J}_{\mathrm{PtC}}=28 \mathrm{~Hz}, \mathrm{C}^{10}\right), 129.7\left(\mathrm{CH}, \mathrm{C}^{5}\right), 131.2$ $(\mathrm{CH}$, aryl naphthoquinone), $131.3(\mathrm{CH}$, aryl naphthoquinone), $135.7\left(\mathrm{CH}, \mathrm{C}^{7}\right), 135.8\left(\mathrm{C}, \mathrm{C}^{8}\right), 136.1$ (C, aryl naphthoquinone), 136.2 (C, aryl naphthoquinone), $138.3\left(\mathrm{CH}, \mathrm{C}^{4}\right), 148.2\left(\mathrm{C}, \mathrm{C}^{9}\right)$, $166.7\left(\mathrm{C}, \mathrm{J}_{\mathrm{PtC}}=40 \mathrm{~Hz}, \mathrm{C}^{2}\right), 188.3(\mathrm{C}, \mathrm{CO}), 188.6(\mathrm{C}, \mathrm{CO})$.

IR, $\mathrm{KBr}$ pellets $\left(\mathrm{cm}^{-1}\right): v_{\mathrm{C}=\mathrm{O}}=1627,1586$.

Elemental anal. (\%) for $\mathrm{C}_{21} \mathrm{H}_{17} \mathrm{NO}_{2}$ PtS: C 46.49, H 3.16, N 2.58 . Found: C 46.62, H 3.22, N 2.47 .

\subsubsection{Synthesis of complex $\mathbf{4 a}$}

Reaction time: $60 \mathrm{~min}$. Temperature: $45^{\circ} \mathrm{C}$. Yield $45 \%$. Color: deep yellow

${ }^{1} \mathbf{H}-\mathrm{NMR}\left(\mathbf{3 0 0} \mathbf{~ M H z}, \mathbf{C D C l}_{\mathbf{3}}, \mathbf{T}=\mathbf{2 9 8} \mathbf{K}, \mathbf{~ p p m}\right) \delta: 1.31\left(\mathrm{~s}, 9 \mathrm{H},{ }^{t} \mathrm{Bu}\right)$, $3.19\left(\mathrm{~s}, 3 \mathrm{H}, \mathrm{J}_{\mathrm{PtH}}=7.9 \mathrm{~Hz}\right.$ quinoline- $\left.\mathrm{CH}_{3}\right), 3.60\left(\mathrm{~s}, 6 \mathrm{H}, \mathrm{OCH}_{3}\right), 3.65(\mathrm{~s}$, $\left.6 \mathrm{H}, \mathrm{OCH}_{3}\right), 3.62\left(\mathrm{~d}, 1 \mathrm{H}, \mathrm{J}=8.7 \mathrm{~Hz}, \mathrm{JPtH}_{\mathrm{PtH}}=88.0 \mathrm{~Hz}, \mathrm{CH}=\mathrm{CH}\right), 3.85(\mathrm{~d}$, $\left.1 \mathrm{H}, \mathrm{J}=8.7 \mathrm{~Hz}, \mathrm{JPtH}_{\mathrm{PtH}}=86.4 \mathrm{~Hz}, \mathrm{CH}=\mathrm{CH}\right), 7.54-762\left(\mathrm{~m}, 2 \mathrm{H}, \mathrm{H}^{3}, \mathrm{H}^{6}\right)$, $7.88\left(\mathrm{dd}, 1 \mathrm{H}, \mathrm{J}=8.1,1.3 \mathrm{~Hz}, \mathrm{H}^{5}\right), 8.02\left(\mathrm{dd}, 1 \mathrm{H}, \mathrm{J}=7.3,1.4 \mathrm{~Hz}, \mathrm{H}^{7}\right)$, $8.30\left(\mathrm{~d}, 1 \mathrm{H}, \mathrm{J}=8.4, \mathrm{~Hz}, \mathrm{H}^{4}\right)$.

${ }^{13} \mathbf{C}\left\{{ }^{1} \mathbf{H}\right\}-N M R\left(\mathbf{C D C l}_{3}, \mathbf{T}=\mathbf{2 9 8} \mathbf{K}, \mathbf{p p m}\right) \delta: 30.0\left(\mathrm{CH}_{3}, \mathrm{CMe}_{3}\right), 32.5$ $\left(\mathrm{CH}_{3}\right.$, quinoline- $\left.\mathrm{CH}_{3}\right), 34.6$ (bs, $\left.\mathrm{CH}, \mathrm{CH}=\mathrm{CH}\right), 37.2$ (bs, $\mathrm{CH}, \mathrm{CH}=\mathrm{CH}$ ), $50.7\left(\mathrm{CH}_{3}, \mathrm{OCH}_{3}\right), 50.8\left(\mathrm{CH}_{3}, \mathrm{OCH}_{3}\right), 55.9\left(\mathrm{C}, \mathrm{CMe}_{3}\right), 124.1(\mathrm{CH}$, $\left.\mathrm{JPtC}_{\mathrm{PtC}}=27 \mathrm{~Hz} \mathrm{C}^{3}\right), 126.3\left(\mathrm{CH}, \mathrm{C}^{6}\right), 128.6\left(\mathrm{C}, \mathrm{C}^{10}\right), 130.3\left(\mathrm{CH}, \mathrm{C}^{5}\right)$, $133.6\left(\mathrm{C}, \mathrm{C}^{8}\right), 137.4\left(\mathrm{CH}, \mathrm{C}^{7}\right), 137.9\left(\mathrm{CH}, \mathrm{C}^{4}\right), 150.4\left(\mathrm{C}, \mathrm{C}^{9}\right), 165.0$ $\left(\mathrm{CH}, \mathrm{J}_{\mathrm{PtC}}=39 \mathrm{~Hz}, \mathrm{C}^{2}\right), 176.1(\mathrm{C}, \mathrm{CO}), 176.6(\mathrm{C}, \mathrm{CO})$.

IR, $\mathrm{KBr}$ pellets $\left(\mathrm{cm}^{-1}\right): v_{\mathrm{C}=\mathrm{O}}=1686$.

Elemental anal. (\%) for $\mathrm{C}_{20} \mathrm{H}_{25} \mathrm{NO}_{4}$ PtS: C 42.10, H 4.42, N 2.45. Found: C 42.23, H 4.28, N 2.61.

\subsubsection{Synthesis of complex $\mathbf{4 b}$}

Reaction time: $60 \mathrm{~min}$. Temperature: $45^{\circ} \mathrm{C}$. Yield 52\%. Color: pale brown.

${ }^{1} \mathbf{H}-\mathrm{NMR}$ (300 $\left.\mathbf{M H z}, \mathbf{C D C l}_{\mathbf{3}}, \mathbf{T}=\mathbf{2 9 8} \mathbf{K}, \mathbf{p p m}\right) \delta: 1.41\left(\mathrm{~s}, 9 \mathrm{H},{ }^{t} \mathrm{Bu}\right)$, $2.82\left(\mathrm{~d}, 1 \mathrm{H}, \mathrm{J}=7.8 \mathrm{~Hz}, \mathrm{~J}_{\mathrm{PtH}}=86.1 \mathrm{~Hz}, \mathrm{CH}=\mathrm{CH}\right), 2.96(\mathrm{~d}, 1 \mathrm{H}$, $\mathrm{J}=7.9 \mathrm{~Hz}, \mathrm{JPtH}=87.5 \mathrm{~Hz}, \mathrm{CH}=\mathrm{CH}), 3.24\left(\mathrm{~s}, 3 \mathrm{H}, \mathrm{J}_{\mathrm{PtH}}=8.6 \mathrm{~Hz}\right.$ quinoline- $\left.\mathrm{CH}_{3}\right), 7.63-7.69\left(\mathrm{~m}, 2 \mathrm{H}, \mathrm{H}^{3} \mathrm{H}^{6}\right), 7.96(\mathrm{dd}, 1 \mathrm{H}, \mathrm{J}=8.1,1.4 \mathrm{~Hz}$, $\left.\mathrm{H}^{5}\right), 8.08\left(\mathrm{dd}, 1 \mathrm{H}, \mathrm{J}=7.3,1.4 \mathrm{~Hz}, \mathrm{H}^{7}\right), 8.40\left(\mathrm{~d}, 1 \mathrm{H}, \mathrm{J}=8.4, \mathrm{~Hz}, \mathrm{H}^{4}\right)$.

${ }^{13} \mathbf{C}\left\{{ }^{1} \mathbf{H}\right\}-N M R\left(\mathbf{C D C l}_{3}, \mathbf{T}=\mathbf{2 9 8} \mathbf{K}, \mathbf{p p m}\right) \delta: 2.1(\mathrm{CH}, \mathrm{JPtC}=404 \mathrm{~Hz}$ $\mathrm{CH}=\mathrm{CH}), 10.0\left(\mathrm{CH}, \mathrm{J}_{\mathrm{PtC}}=437 \mathrm{~Hz}, \mathrm{CH}=\mathrm{CH}\right), 30.2\left(\mathrm{CH}_{3}, \mathrm{CMe}_{3}\right), 32.5$ $\left(\mathrm{CH}_{3}\right.$, quinoline- $\left.\mathrm{CH}_{3}\right), 57.3\left(\mathrm{C}, \mathrm{CMe}_{3}\right), 123.8(\mathrm{C}, \mathrm{CN}), 124.0(\mathrm{C}, \mathrm{CN})$, $124.2\left(\mathrm{CH}, \mathrm{JPtC}_{\mathrm{PtC}}=27 \mathrm{~Hz}, \mathrm{C}^{3}\right), 126.9\left(\mathrm{CH}, \mathrm{C}^{6}\right), 128.7\left(\mathrm{C}, \mathrm{J}_{\mathrm{PtC}}=26 \mathrm{~Hz}\right.$, $\left.\mathrm{C}^{10}\right), 130.9\left(\mathrm{CH}, \mathrm{C}^{5}\right), 132.3\left(\mathrm{C}, \mathrm{JPtC}_{\mathrm{PtC}}=27 \mathrm{~Hz}, \mathrm{C}^{8}\right), 138.4\left(\mathrm{CH}, \mathrm{C}^{7}\right)$, $138.5\left(\mathrm{CH}, \mathrm{C}^{4}\right), 150.4\left(\mathrm{C}, \mathrm{C}^{9}\right), 164.9\left(\mathrm{CH}, \mathrm{J}_{\mathrm{PtC}}=40 \mathrm{~Hz}, \mathrm{C}^{2}\right)$.

IR, $\mathrm{KBr}$ pellets $\left(\mathrm{cm}^{-1}\right): v_{\mathrm{CN}}=2196$.

Elemental anal. (\%) for $\mathrm{C}_{18} \mathrm{H}_{19} \mathrm{~N}_{3}$ PtS: C 42.85, H 3.80, N 8.33. Found: C 42.99, H 3.71, N 8.18.

\subsubsection{Synthesis of complex $\mathbf{4 c}$}

Reaction time: $60 \mathrm{~min}$. Temperature: $45^{\circ} \mathrm{C}$. Yield $61 \%$. Color: brown.

${ }^{1} \mathbf{H}-\mathrm{NMR}\left(\mathbf{3 0 0} \mathbf{~ M H z}, \mathbf{C D C l}_{\mathbf{3}}, \mathbf{T}=\mathbf{2 9 8} \mathbf{K}, \mathbf{p p m}\right): \delta 1.37\left(\mathrm{~s}, 9 \mathrm{H},{ }^{t} \mathrm{Bu}\right)$, $3.21\left(\mathrm{~s}, 3 \mathrm{H}, \mathrm{J}_{\mathrm{PtH}}=8.8 \mathrm{~Hz}\right.$ quinoline- $\left.\mathrm{CH}_{3}\right), 3.77(\mathrm{~d}, 1 \mathrm{H}, \mathrm{J}=3.9 \mathrm{~Hz}$, $\left.\mathrm{J}_{\mathrm{PtH}}=81.8 \mathrm{~Hz}, \mathrm{CH}=\mathrm{CH}\right), 3.86\left(\mathrm{~d}, 1 \mathrm{H}, \mathrm{J}=3.9 \mathrm{~Hz}, \mathrm{JPtH}_{\mathrm{PtH}}=82.9 \mathrm{~Hz}\right.$, 
$\mathrm{CH}=\mathrm{CH}), 7.61-7.66\left(\mathrm{~m}, 2 \mathrm{H}, \mathrm{H}^{3}, \mathrm{H}^{6}\right), 7.94(\mathrm{dd}, 1 \mathrm{H}, \mathrm{J}=8.1,1.3 \mathrm{~Hz}$, $\left.\mathrm{H}^{5}\right), 8.05\left(\mathrm{dd}, 1 \mathrm{H}, \mathrm{J}=7.3,1.3 \mathrm{~Hz}, \mathrm{H}^{7}\right), 8.37\left(\mathrm{~d}, 1 \mathrm{H}, \mathrm{J}=8.4, \mathrm{H}^{4}\right)$.

${ }^{13} \mathbf{C}\left\{{ }^{1} \mathbf{H}\right\}-N M R\left(\mathbf{C D C l}_{\mathbf{3}}, \mathbf{T}=\mathbf{2 9 8} \mathbf{K}, \mathbf{p p m}\right) \delta: 26.4\left(\mathrm{CH}, \mathrm{J}_{\mathrm{PtH}}=369 \mathrm{~Hz}\right.$, $\mathrm{CH}=\mathrm{CH}), 30.3\left(\mathrm{~s}, \mathrm{CH}_{3}, \mathrm{CMe}_{3}\right), 32.8\left(\mathrm{CH}_{3}, \mathrm{JPtC}_{\mathrm{PtC}}=28 \mathrm{~Hz}, \mathrm{CH}_{3}\right.$-quinoline), 34.3 (bs, $\mathrm{CH}, \mathrm{CH}=\mathrm{CH}), 57.6\left(\mathrm{C}, \mathrm{CMe}_{3}\right), 124.5\left(\mathrm{CH}, \mathrm{J}_{\mathrm{PtC}}=28 \mathrm{~Hz}\right.$, $\left.\mathrm{C}^{3}\right), 126.8\left(\mathrm{CH}, \mathrm{C}^{6}\right), 128.6\left(\mathrm{C}, \mathrm{J}_{\mathrm{PtC}}=25 \mathrm{~Hz}, \mathrm{C}^{10}\right), 130.9\left(\mathrm{CH}, \mathrm{C}^{5}\right), 132.3$ $\left(\mathrm{C}, \mathrm{J}_{\mathrm{PtC}}=32 \mathrm{~Hz} \mathrm{C}^{8}\right), 138.3\left(\mathrm{CH}, \mathrm{C}^{7}\right), 138.4\left(\mathrm{CH}, \mathrm{C}^{4}\right), 150.3\left(\mathrm{C}, \mathrm{C}^{9}\right)$, 165.6 (bs, $\mathrm{CH}, \mathrm{C}^{2}$ ), 173.6 (C, CO), 174.5 (C, CO).

IR, $\mathrm{KBr}$ pellets $\left(\mathrm{cm}^{-1}\right): v_{\mathrm{C}=\mathrm{O}}=1798,1731$.

Elemental anal. (\%) for $\mathrm{C}_{18} \mathrm{H}_{19} \mathrm{NO}_{3}$ PtS: C 41.22, $\mathrm{H} 3.65$, N 2.67. Found: C 41.32, H 3.78, N 2.49.

\subsubsection{Synthesis of complex $\mathbf{4 d}$}

Reaction time: $60 \mathrm{~min}$. Temperature: $45^{\circ} \mathrm{C}$. Yield $61 \%$. Color: greenish.

${ }^{1} \mathbf{H}-\mathrm{NMR}$ (300 MHz, $\left.\mathbf{C D C l}_{\mathbf{3}}, \mathbf{T}=\mathbf{2 9 8} \mathbf{K}, \mathbf{p p m}\right) \delta: 1.30\left(\mathrm{bs}, 9 \mathrm{H},{ }^{t} \mathrm{Bu}\right.$ ), 3.21 (bs, $3 \mathrm{H}, \mathrm{J}_{\mathrm{PtH}}=8.8 \mathrm{~Hz}$ quinoline- $\mathrm{CH}_{3}$ ), 4.55, 4.58 (AB system, $\left.2 \mathrm{H}, \mathrm{J}=6.6 \mathrm{~Hz}, \mathrm{~J}_{\mathrm{PtH}}=74.4,73.0 \mathrm{~Hz}, \mathrm{CH}=\mathrm{CH}\right), 7.40-7.56(\mathrm{~m}, 4 \mathrm{H}$, aryl-nq, $\left.\mathrm{H}^{3}, \mathrm{H}^{6}\right), 7.81\left(\mathrm{dd}, 1 \mathrm{H}, \mathrm{J}=8.0,1.3 \mathrm{~Hz}, \mathrm{H}^{5}\right), 7.94(\mathrm{dd}, 1 \mathrm{H}$, $\left.\mathrm{J}=7.3,1.3 \mathrm{~Hz}, \mathrm{H}^{7}\right), 8.00-8.09(\mathrm{~m}, 2 \mathrm{H}$, aryl-nq), $8.24(\mathrm{~d}, 1 \mathrm{H}$, $\left.\mathrm{J}=8.4 \mathrm{~Hz}, \mathrm{H}^{4}\right)$.

${ }^{13} \mathbf{C}\left\{{ }^{1} \mathbf{H}\right\}$-NMR $\left(\mathbf{C D C l}_{\mathbf{3}}, \mathbf{T}=\mathbf{2 9 8} \mathbf{K}, \mathbf{p p m}\right) \delta: 30.1\left(\mathrm{CH}_{3}, \mathrm{CMe}_{3}\right), 31.2$ $\left(\mathrm{CH}_{3}, \mathrm{CH}_{3}\right.$-quinoline), $43.3\left(\mathrm{CH}, \mathrm{J}_{\mathrm{PtC}}=344 \mathrm{~Hz} \mathrm{CH}=\mathrm{CH}\right), 50.3$ (bs, $\mathrm{CH}$, $\mathrm{CH}=\mathrm{CH}), 124.6\left(\mathrm{CH}, \mathrm{J}_{\mathrm{PtC}}=34 \mathrm{~Hz}, \mathrm{C}^{3}\right), 125.4(\mathrm{CH}$, aryl-nq), 125.5 $\left(\mathrm{CH}\right.$, aryl-nq), $126.4\left(\mathrm{CH}, \mathrm{C}^{6}\right), 128.5\left(\mathrm{C}, \mathrm{C}^{10}\right), 130.5\left(\mathrm{CH}, \mathrm{C}^{5}\right), 131.2$ $\left(\mathrm{CH}\right.$, aryl-nq), $131.2\left(\mathrm{CH}\right.$, aryl-nq), $133.0\left(\mathrm{C}, \mathrm{C}^{8}\right), 136.3(\mathrm{C}$, arylnq), $136.4\left(\mathrm{C}\right.$, aryl-nq), $137.8\left(\mathrm{CH}, \mathrm{C}^{7}\right), 138.0\left(\mathrm{CH}, \mathrm{C}^{4}\right), 150.4(\mathrm{C}$, $\left.\mathrm{C}^{9}\right), 166.3\left(\mathrm{CH}, \mathrm{JPtC}_{\mathrm{PtC}}=31 \mathrm{~Hz}, \mathrm{C}^{2}\right), 190.9(\mathrm{C}, \mathrm{CO})$; one CO signal is not detected.

IR, $\mathrm{KBr}$ pellets $\left(\mathrm{cm}^{-1}\right): v_{\mathrm{C}=\mathrm{O}}=1641,1625$.

Elemental anal. (\%) for $\mathrm{C}_{24} \mathrm{H}_{23} \mathrm{NO}_{2}$ PtS: C 49.31, H 3.97, N 2.40. Found: C 49.47, H 4.12, N 2.35.

\subsubsection{Synthesis of complex $\mathbf{2 e}$}

$0.0500 \mathrm{~g} \quad(0.090 \mathrm{mmol})$ of complex 2a and $0.0141 \mathrm{~g}$ $(0.099 \mathrm{mmol})$ of dimethyl but-2-yneate (DMA) were dissolved in $8 \mathrm{ml}$ of anhydrous $\mathrm{CH}_{2} \mathrm{Cl}_{2}$ in a $50 \mathrm{ml}$ flask under inert atmosphere (Ar). The resulting solution was vigorously stirred for $10 \mathrm{~min}$ and then its volume reduced under vacuum. Addition of diethyl ether induced the precipitation of $0.0388 \mathrm{~g}$ (yield $70 \%$ ) of the title complex as a microcrystalline ochre solid which was filtered off on a gooch and dried under vacuum.

${ }^{1} \mathrm{H}$-NMR (300 MHz, $\left.\mathbf{C D C l}_{\mathbf{3}}, \mathbf{T}=\mathbf{2 9 8} \mathbf{K}, \mathbf{p p m}\right) \delta: 1.47\left(\mathrm{~s}, 9 \mathrm{H},{ }^{t} \mathrm{Bu}\right.$ ), $3.86\left(\mathrm{~s}, 3 \mathrm{H}, \mathrm{OCH}_{3}\right), 3.92\left(\mathrm{~s}, 3 \mathrm{H}, \mathrm{OCH}_{3}\right), 7.53(\mathrm{dd}, 1 \mathrm{H}, \mathrm{J}=8.4,4.9 \mathrm{~Hz}$, $\left.\mathrm{H}^{3}\right), 7.69\left(\mathrm{dd}, 1 \mathrm{H}, \mathrm{J}=8.2,7.3 \mathrm{~Hz}, \mathrm{H}^{6}\right), 7.93(\mathrm{dd}, 1 \mathrm{H}, \mathrm{J}=8.2,1.2 \mathrm{~Hz}$, $\left.\mathrm{H}^{5}\right), 8.13\left(\mathrm{dd}, 1 \mathrm{H}, \mathrm{J}=7.3,1.2 \mathrm{~Hz}, \mathrm{H}^{7}\right), 8.48(\mathrm{dd}, 1 \mathrm{H}, \mathrm{J}=8.4,1.5 \mathrm{~Hz}$, $\left.\mathrm{H}^{4}\right), 10.29\left(\mathrm{dd}, 1 \mathrm{H}, \mathrm{J}=4.9,1.5 \mathrm{~Hz}, \mathrm{JPtH}_{\mathrm{PtH}}=37.6 \mathrm{~Hz}, \mathrm{H}^{2}\right)$.

${ }^{13} \mathbf{C}\left\{{ }^{1} \mathbf{H}\right\}-N M R\left(\mathbf{C D C l}_{3}, \mathbf{T}=\mathbf{2 9 8} \mathbf{K}, \mathbf{p p m}\right) \delta: 30.1\left(\mathrm{CH}_{3}, \mathrm{~J}_{\mathrm{PtC}}=20 \mathrm{~Hz}\right.$, $\left.\mathrm{CMe}_{3}\right), 51.9\left(\mathrm{CH}_{3}, \mathrm{OCH}_{3}\right), 52.0\left(\mathrm{CH}_{3}, \mathrm{OCH}_{3}\right), 56.5\left(\mathrm{C}, \mathrm{CMe}_{3}\right), 109.4(\mathrm{C}$, $\mathrm{C} \equiv), 118.9(\mathrm{C}, \mathrm{C} \equiv), 123.8\left(\mathrm{CH}, \mathrm{JPtC}_{\mathrm{PtC}}=41 \mathrm{~Hz} \mathrm{C}^{3}\right), 127.5\left(\mathrm{CH}, \mathrm{C}^{6}\right), 130.3$ $\left(\mathrm{CH}, \mathrm{C}^{5}\right), 130.5\left(\mathrm{C}, \mathrm{J}_{\mathrm{PtC}}=24 \mathrm{~Hz}, \mathrm{C}^{10}\right), 134.5\left(\mathrm{C}, \mathrm{J}_{\mathrm{PtC}}=27 \mathrm{~Hz} \mathrm{C}^{8}\right), 137.0$ $\left(\mathrm{CH}, \mathrm{C}^{4}\right), 137.8\left(\mathrm{CH}, \mathrm{C}^{7}\right), 149.7\left(\mathrm{C}, \mathrm{C}^{9}\right), 158.2\left(\mathrm{CH}, \mathrm{J}_{\mathrm{PtC}}=50 \mathrm{~Hz}, \mathrm{C}^{2}\right)$, 159.5 (C, CO), 161.7 (C, CO).

IR, $\mathrm{KBr}$ pellets $\left(\mathrm{cm}^{-1}\right): v_{\mathrm{C}=\mathrm{O}}=1750,1680 ; v_{\mathrm{C}-\mathrm{O}}=1216$.

Elemental anal. (\%) for $\mathrm{C}_{19} \mathrm{H}_{21} \mathrm{NO}_{4} \mathrm{PtS}$ : C 41.15, H 3.82, N 2.53 . Found: C 41.34, H 3.92, N 2.41.

\subsubsection{Synthesis of the tautomeric mixture $\mathbf{2} \boldsymbol{i}, \mathbf{2} \mathbf{j}$}

$0.0400 \mathrm{~g}(0.0719 \mathrm{mmol})$ of complex $2 \mathrm{a}$ and $0.0325 \mathrm{~g}$ $(0.2157 \mathrm{mmol})$ of 3-chloro-1-phenyl propyne were dissolved in $5 \mathrm{ml}$ of anhydrous $\mathrm{CH}_{2} \mathrm{Cl}_{2}$ in a $50 \mathrm{ml}$ flask under inert atmosphere (Ar). The mixture was vigorously stirred for $27 \mathrm{~h}$ at $28^{\circ} \mathrm{C}$, eventually treated with activated carbon and filtered with a millipore device. The clear solution was concentrated at small volume under vacuum and the tautomeric mixture precipitated as a pink solid by addition of diethyl ether. The complexes were filtered off on a gooch (0.0224 g; yield 55\%) and dried under vacuum.

Propargyl tautomer (50\%) ${ }^{1} \mathrm{H}-\mathrm{NMR}$ (300 $\mathrm{MHz}, \mathrm{CD}_{2} \mathrm{Cl}_{2}, \mathrm{~T}=298$ $\mathrm{K}$, ppm, selected peaks) $\delta: 1.41\left(\mathrm{~s}, 9 \mathrm{H},{ }^{t} \mathrm{Bu}\right), 2.69,2.82$ (AB system, $\left.2 \mathrm{H}, \mathrm{J}=14.2 \mathrm{~Hz}, \mathrm{~J}_{\mathrm{PtH}}=100.7,108.9 \mathrm{~Hz}, \mathrm{CH}_{2} \mathrm{Pt}\right), 8.57(\mathrm{dd}, 1 \mathrm{H}, \mathrm{J}=8.3$, $\left.1.5 \mathrm{~Hz}, \mathrm{H}^{4}\right), 9.99\left(\mathrm{dd}, 1 \mathrm{H}, \mathrm{J}=5.1,1.5 \mathrm{~Hz}, \mathrm{~J}_{\mathrm{PtH}}=19.2 \mathrm{~Hz}, \mathrm{H}^{2}\right)$.

Allenyl tautomer (50\%) ${ }^{1} \mathrm{H}-\mathrm{NMR}\left(300 \mathrm{MHz}, \mathrm{CD}_{2} \mathrm{Cl}_{2}, \mathrm{~T}=298 \mathrm{~K}\right.$, ppm) $\delta: 1.32\left(\mathrm{~s}, 9 \mathrm{H},{ }^{t} \mathrm{Bu}\right), 4.56$ (bs, $\left.2 \mathrm{H}, \mathrm{J}_{\mathrm{PtH}}=39.6 \mathrm{~Hz}, \mathrm{CH}_{2}=\right), 8.61$ $\left(\mathrm{dd}, 1 \mathrm{H}, \mathrm{J}=8.3,1.5 \mathrm{~Hz}, \mathrm{H}^{4}\right), 10.07(\mathrm{dd}, 1 \mathrm{H}, \mathrm{J}=5.1,1.5 \mathrm{~Hz}$, $\left.\mathrm{JPtH}_{\mathrm{P}}=20.4 \mathrm{~Hz}, \mathrm{H}^{2}\right)$.

IR, $\mathrm{KBr}$ pellets $\left(\mathrm{cm}^{-1}\right)$ : (Propargyl tautomer $) v_{\mathrm{C} \equiv \mathrm{C}}=2187 ;($ Allenyl tautomer) $v_{\mathrm{C}=\mathrm{C}=\mathrm{C}}=1905$.

Elemental anal. (\%) for $\mathrm{C}_{22} \mathrm{H}_{22}$ ClNPtS: C 46.93, H $3.94 \mathrm{~N} 2.49$. Found: C 47.09, H 4.03 N 2.32 .

\subsubsection{Synthesis of the tautomeric mixture $\mathbf{4 i}$}

The title complex was synthesized starting from the complex $\mathbf{4 a}$ by a similar procedure as that followed in the synthesis of the previously described tautomeric mixture $\mathbf{2} \mathbf{i}, \mathbf{2} \mathbf{j}$. In this case, however, only the tautomer $\mathbf{4 i}$ was obtained as a pale brown solid (Yield $81 \%)$.

${ }^{1} \mathbf{H}-\mathrm{NMR}$ (300 MHz, $\left.\mathbf{C D C l}_{\mathbf{3}}, \mathbf{T}=\mathbf{2 9 8} \mathbf{K}, \mathbf{p p m}\right) \delta: 1.23\left(\mathrm{~s}, 9 \mathrm{H},{ }^{t} \mathrm{Bu}\right.$ ), $3.34\left(\mathrm{~s}, 3 \mathrm{H}\right.$, quinoline- $\left.\mathrm{CH}_{3}\right)$, 4.59. $4.67(\mathrm{AB}$ system, $2 \mathrm{H}, \mathrm{J}=9.8 \mathrm{~Hz}$, $\left.\mathrm{J}_{\mathrm{PtH}}=42.1 \mathrm{~Hz}, \mathrm{CH}_{2}=\right), 7.55\left(\mathrm{~d}, 1 \mathrm{H}, \mathrm{J}=8.5, \mathrm{H}^{3}\right), 7.63(\mathrm{dd}, 1 \mathrm{H}, \mathrm{J}=8.0$, 7.3 Hz, $\left.\mathrm{H}^{6}\right), 7.85-7.88(\mathrm{~m}, 2 \mathrm{H}, \mathrm{Ph}), 7.96-8.02\left(\mathrm{~m}, 2 \mathrm{H}, \mathrm{H}^{5}, \mathrm{H}^{7}\right), 8.35$ $\left(\mathrm{d}, 1 \mathrm{H}, \mathrm{J}=8.5, \mathrm{~Hz}, \mathrm{H}^{4}\right)$.

${ }^{13} \mathbf{C}\left\{{ }^{1} \mathbf{H}\right\}-N M R\left(\mathbf{C D}_{\mathbf{2}} \mathbf{C l}_{\mathbf{2}}, \mathbf{T}=\mathbf{2 5 3} \mathbf{K}, \mathbf{p p m}\right) \delta: 28.3\left(\mathrm{CH}_{3}, \mathrm{CMe}_{3}\right), 28.4$ $\left(\mathrm{CH}_{3}\right.$, quinoline- $\left.\mathrm{CH}_{3}\right), 57.4\left(\mathrm{C}, \mathrm{CMe}_{3}\right), 68.9\left(\mathrm{CH}_{2}, \mathrm{CH}_{2}=\right), 76.2(\mathrm{C}$, $\mathrm{PhC}=), 125.3(\mathrm{CH}, \mathrm{Ph}), 126.3\left(\mathrm{CH}, \mathrm{C}^{3}\right), 126.9\left(\mathrm{CH}, \mathrm{C}^{6}\right), 127.6(\mathrm{CH}$, $\mathrm{Ph}), 128.2\left(\mathrm{C}, \mathrm{C}^{10}\right), 129.1(\mathrm{CH}, \mathrm{Ph}), 130.5\left(\mathrm{C}, \mathrm{C}^{8}\right), 131.2\left(\mathrm{CH}, \mathrm{C}^{5}\right)$, $135.2\left(\mathrm{CH}, \mathrm{C}^{7}\right), 138.1\left(\mathrm{CH}, \mathrm{C}^{4}\right), 142.2(\mathrm{C}, \mathrm{Ph}), 149.5\left(\mathrm{C}, \mathrm{C}^{9}\right), 166.8$ $\left(\mathrm{CH}, \mathrm{C}^{2}\right), 204.7(\mathrm{C},=\mathrm{C}=)$.

IR, $\mathrm{KBr}$ pellets $\left(\mathrm{cm}^{-1}\right): v_{\mathrm{C}=\mathrm{C}=\mathrm{C}}=1907$.

Elemental anal. (\%) for $\mathrm{C}_{23} \mathrm{H}_{24}$ ClNPtS: C 47.87, H 4.19, N 2.43. Found: C 47.99, H 4.32, N 2.47.

\subsubsection{Synthesis of the complex $\mathbf{2 h}$}

$0.0509 \mathrm{~g}(0.091 \mathrm{mmol})$ of complex 2a and $0.0254 \mathrm{~g}$ of allylchloride were dissolved in $8 \mathrm{ml}$ of anhydrous $\mathrm{CH}_{2} \mathrm{Cl}_{2}$ at R.T. under inert atmosphere ( $\mathrm{Ar}$ ) in a two necked $50 \mathrm{ml}$ flask. The mixture was stirred at RT for $4 \mathrm{~h}$ and evaporated to small volume under vacuum. Activated carbon was added to the solution which was then filtered with a millipore device. Addition of diethyl ether induced the precipitation of the title compound $(0.0373 \mathrm{~g}$; yield $83 \%)$ which was filtered off on a gooch and dried under vacuum.

${ }^{1} \mathbf{H}$-NMR (300 MHz, $\mathbf{C D}_{2} \mathbf{C l}_{2}, \mathbf{T}=\mathbf{2 9 8} \mathbf{K}, \mathbf{p p m}$ ) $\delta$ : $1.33\left(\mathrm{~s}, 9 \mathrm{H},{ }^{t} \mathrm{Bu}\right.$ ), 2.88, 2.93 (AB part of an ABX system, $2 \mathrm{H}, \mathrm{J}_{\mathrm{AB}}=8.3, \mathrm{~J}_{\mathrm{AC}}=\mathrm{J}_{\mathrm{BC}} 8.8 \mathrm{~Hz}$, $\left.\mathrm{J}_{\mathrm{PtH}}=108.9, \quad 80.6 \mathrm{~Hz}, \quad \mathrm{Pt}-\mathrm{CH}_{2}\right), 4.72(\mathrm{dd}, 1 \mathrm{H}, \mathrm{J}=9.9, \quad 2.8 \mathrm{~Hz}$, $\left.\mathrm{J}_{\mathrm{PtH}}=15.2 \mathrm{~Hz},=\mathrm{CH}_{2}\right), 5.06\left(\mathrm{~d}, 1 \mathrm{H}, \mathrm{J}=17.1 \mathrm{~Hz}, \mathrm{~J}_{\mathrm{PtH}}=14.6 \mathrm{~Hz},=\mathrm{CH}_{2}\right)$, $6.20(\mathrm{~m}, 1 \mathrm{H}, \mathrm{CH}=), 7.66-7.76\left(\mathrm{~m}, 2 \mathrm{H}, \mathrm{H}^{3}, \mathrm{H}^{6}\right), 8.06-8.12(\mathrm{~m}, 2 \mathrm{H}$, $\left.\mathrm{H}^{5}, \mathrm{H}^{7}\right), 8.55\left(\mathrm{dd}, 1 \mathrm{H}, \mathrm{J}=8.2,1.4 \mathrm{~Hz}, \mathrm{H}^{4}\right), 9.91(\mathrm{dd}, 1 \mathrm{H}, \mathrm{J}=5.0$, $\left.1.4 \mathrm{~Hz}, \mathrm{~J}_{\mathrm{PtH}}=17.4 \mathrm{~Hz}, \mathrm{H}^{2}\right)$.

${ }^{13} \mathbf{C}\left\{{ }^{1} \mathbf{H}\right\}-N M R\left(\mathbf{C D}_{\mathbf{2}} \mathbf{C l}_{\mathbf{2}}, \mathbf{T}=\mathbf{2 9 8} \mathbf{K}, \mathbf{p p m}\right) \delta: 1.3\left(\mathrm{CH}_{2}, \mathrm{JPtC}=583-\right.$ $\left.\mathrm{Hz}, \mathrm{PtCH}_{2}\right), 28.9\left(\mathrm{CH}_{3}, \mathrm{JPtC}_{\mathrm{PtC}} 30 \mathrm{~Hz}, \mathrm{CMe}_{3}\right), 59.0\left(\mathrm{C}, \mathrm{CMe}_{3}\right), 107.1$ $\left(\mathrm{CH}_{2}, \mathrm{~J}_{\mathrm{PtC}}=38 \mathrm{~Hz},=\mathrm{CH}_{2}\right), 123.7\left(\mathrm{CH}, \mathrm{J}_{\mathrm{PtC}}=39 \mathrm{~Hz}, \mathrm{C}^{3}\right), 127.4(\mathrm{CH}$, $\left.\mathrm{C}^{6}\right), 130.4\left(\mathrm{C}, \mathrm{J}_{\mathrm{PtC}}=21 \mathrm{~Hz}, \mathrm{C}^{10}\right), 131.1\left(\mathrm{CH}, \mathrm{C}^{5}\right), 131.4\left(\mathrm{C}, \mathrm{JPtC}_{\mathrm{PtC}}=32 \mathrm{~Hz}\right.$, $\left.\mathrm{C}^{8}\right), 135.7\left(\mathrm{CH}, \mathrm{J}_{\mathrm{PtC}}=21 \mathrm{~Hz}, \mathrm{C}^{7}\right), 137.9\left(\mathrm{CH}, \mathrm{C}^{4}\right), 146.2\left(\mathrm{CH}, \mathrm{J}_{\mathrm{PtC}}=51-\right.$ $\mathrm{Hz}, \mathrm{CH}=), 148.9\left(\mathrm{C}, \mathrm{C}^{9}\right), 150.9\left(\mathrm{CH}, \mathrm{C}^{2}\right)$

Elemental anal. (\%) for $\mathrm{C}_{16} \mathrm{H}_{20}$ ClNPtS: C 39.30, H 4.12, N 2.86 . Found: C 39.44, H 4.27, N 2.71.

\section{Appendix A. Supplementary data}

CCDC 1531749 contains the supplementary crystallographic data. These data can be obtained free of charge via http://dx.doi. 
org/10.1016/j.poly.2017.03.053, or from the Cambridge Crystallographic Data Centre, 12 Union Road, Cambridge CB2 1EZ, UK; fax: (+44) 1223-336-033; or e-mail: deposit@ccdc.cam.ac.uk. Supplementary data associated with this article can be found, in the online version, at http://dx.doi.org/10.1016/j.poly.2017.03.053.

\section{References}

[1] (a) J. Tsuji, Palladium Reagents and Catalysts, Wiley, Chichester, 1995; (b) E. Negishi, Handbok of organometallic chemistry for organic synthesis, John Wiley \& Sons, New York, 2002;

c) J. Tsuji, T. Mandai, Angew. Chem. Int. Ed. 34 (1995) 2589-2612;

d) R. Zimmer, C.U. Dinesh, E. Nandanan, F.A. Khan, Chem. Rev. 100 (2000) 3067-3125;

e) A. Wojcicki, Inorg. Chem. Commun. 5 (2002) 82-97;

f) S. Ma, Aldrich Chim. Acta 40 (2007) 91-102.

g) K. Tutsumi, S. Ogoshi, K. Kakiuchi, S. Nishiguchi, H. Kurosawa, Inorg. Chim. Acta 296 (1999) 37-44;

(h) K. Tutsumi, T. Yabukami, K. Fushimoto, T. Kawase, T. Morimoto, K. Kakiuchi, Organometallics 22 (2003) 2996-2999;

(i) J.-T. Chen, Coord. Chem. Rev. 190 (192) (1999) 1143-1168;

(j) H. Kurosawa, S. Ogoshi, Bull. Chem. Soc. Jpn. 71 (1998) 973-984;

(k) C.J. Elsevier, H. Klein, K. Rutemberg, P. Vermeer, J. Chem. Soc., Chem. Commun. (1983) 1529-1530;

(I) C.J. Elsevier, H. Kleijn, J. Boersma, P. Vermeer, Organometallics 5 (1986) 716-720;

(m) J.M.A. Wouters, R.A. Klein, C.J. Elsevier, L. Haming, C.H. Stam, Organometallics 13 (1994) 4586-4593;

(n) S. Ogoshi, K. Tutsumi, H. Kurosawa, J. Organomet. Chem. 493 (1995) C19C21;

(o) S. Ogoshi, T. Nishida, Y. Fukunishi, K. Tutsumi, H. Kurosawa, J. Organomet. Chem. 620 (2001) 190-193.

[2] (a) R.F. Heck, Palladium Reagents in Organic Synthesis, Academic Press, New York, 1985:

(b) G. Qiu, Q. Ding, J. Wu, J. Chem. Soc Rev. 42 (2013) 5257-5269;

(c) T. Vlaar, E. Rujiter, B.U.W. Maes, R.V.A. Orru, Angew. Chem. Int. Ed. 52 (2013) 7084-7097:

(d) S. Lang, Chem. Soc. Rev. 42 (2013) 4867-4880;

(e) B. Crociani, in: "Reactions of Coordinated Ligands", New York, Vol. 1, 1982, p. 553 and refs. therein.

[3] (a) R.K. Sharma, D. Katiyar, Synthesis 48 (2016) 2303-2322;

(b) G. Cheng, D. Yang, J. Org. Chem. 35 (2015) 2023-2034;

(c) J.A. Kuzman, L.M. Misch, R. Seshadri, Dalton Trans. 42 (2013) 1465314667.

[4] T. Ishima, N. Matsuda, M. Hurata, F. Ozawa, A. Suzuki, N. Miyaura, Organometallics 15 (1996) 713.

[5] T. Sagawa, Y. Asano, F. Ozawa, Organometallics 21 (2002) 5879-5886.

[6] (a) G.K. Barker, M. Green, J.A.K. Howard, J.L. Spencer, F. Gordon, A. Stone, J. Am. Chem. Soc. 98 (1976) 3373;

(b) G.K. Barker, M. Green, J.A.K. Howard, J.L. Spencer, F. Gordon, A. Stone, J. Am. Chem. Soc. 100 (1978) 1839.

[7] R. Ugo, Coord. Chem. Rev. 3 (1968) 319-344.

[8] (a) F. Hering, U. Radius, Organometallics 34 (2015) 3236-3245;

(b) M. Brendel, C. Braun, F. Rominger, P. Hofmann, Angew. Chem. Int. Ed. 53 (2014) 8741-8745.

[9] L. Ortega-Moreno, R. Peloso, C. Maya, Andrés Suérez, E. Carmona, Chem. Commun. 51 (2015) 17008-17011.

[10] L. Canovese, F. Visentin, Inorg. Chim. Acta 363 (2010) 2375-2386.

[11] L. Canovese, F. Visentin, G. Chessa, C. Santo, P. Uguagliati, L. Maini, M. Polito, Dalton Trans. (2002) 3696-3704.

[12] L. Canovese, F. Visentin, P. Uguagliati, B. Crociani, J. Chem Soc., Dalton Trans. (1996) 1921-1926.

[13] (a) L. Canovese, F. Visentin, G. Chessa, P. Uguagliati, A. Dolmella, J. Organomet. Chem. 601 (2000) 1-15;

(b) L. Canovese, F. Visentin, G. Chessa, G. Gardenal, P. Uguagliati, J. Organomet.
Chem. 622 (2001) 155-165;

(c) L. Canovese, F. Visentin, G. Chessa, P. Uguagliati, C. Levi, A. Dolmella, Organometallics 24 (2005) 5537-5548;

(c) L. Canovese, F. Visentin, G. Chessa, C. Levi, P. Uguagliati, A. Dolmella, G. Bandoli, Organometallics 25 (2006) 5355-5365;

(d) L. Canovese, F. Visentin, C. Santo, A. Dolmella, J. Organomet. Chem. 694 (2009) 411-419;

(e) L. Canovese, F. Visentin, C. Levi, C. Santo, V. Bertolasi, Inorg. Chim. Acta 378 (2011) 239-249;

(f) L. Canovese, F. Visentin, C. Levi, C. Santo, V. Bertolasi, Inorg. Chim. Acta 390 (2012) 105-118;

(g) L. Canovese, T. Scattolin, F. Visentin, C. Santo, J. Organomet. Chem. 834 (2017) 10-21.

[14] (a) L. Canovese, C. Santo, F. Visentin, Organometallics 27 (2008) 3577-3581; (b) L. Canovese, F. Visentin, C. Santo, G. Chessa, V. Bertolasi, Organometallics 29 (2010) 3027-3038;

(c) L. Canovese, F. Visentin, C. Santo, T. Scattolin, V. Bertolasi, Dalton Trans. 44 (2015) 15049-15058.

[15] K. Moseley, P.M. Maitlis, J. Chem Soc., Dalton Trans. (1974) 169-175.

[16] L. Canovese, F. Visentin, C. Biz, T. Scattolin, C. Santo, V. Bertolasi, J. Organomet. Chem. 786 (2015) 21-30.

[17] L. Canovese, F. Visentin, C. Santo, V. Bertolasi, J. Organomet. Chem. 749 (2014) $379-386$.

[18] M.N. Burnett, C.K. Johnson, ORTEP III, R eport ORNL-6895, Oak Ridge National Laboratory, Oak Ridge, TN, 1996.

[19] (a) L. Canovese, F. Visentin, C. Santo, J. Organomet. Chem. 770 (2014) 6-13. (b) L. Canovese, F. Visentin, T. Scattolin, C. Santo, V. Bertolasi, Polyhedron 113 (2016) 25-34;

(c) T. Scattolin, F. Visentin, C. Santo, V. Bertolasi, L. Canovese, Dalton Trans. 45 (2016) 11560-11567.

[20] L. Canovese, F. Visentin, C. Biz, T. Scattolin, C. Santo, V. Bertolasi, Polyhedron 102 (2015) 94-102.

[21] M.J. Frisch, G.W. Trucks, H.B. Schlegel, G.E. Scuseria, M.A. Robb, J.R. Cheeseman, G. Scalmani, V. Barone, B. Mennucci, G.A. Petersson, H. Nakatsuji, M. Caricato, X. Li, H.P. Hratchian, A.F. Izmaylov, J. Bloino, G. Zheng, J.L. Sonnenberg, M. Hada, M. Ehara, K. Toyota, R. Fukuda, J. Hasegawa, M. Ishida, T. Nakajima, Y. Honda, O. Kitao, H. Nakai, T. Vreven, J.A. Montgomery Jr., J.E. Peralta, F. Ogliaro, M. Bearpark, J.J. Heyd, E. Brothers, K.N. Kudin, V.N. Staroverov, R. Kobayashi, J. Normand, K. Raghavachari, A. Rendell, J.C. Burant, S.S. Iyengar, J. Tomasi, M. Cossi, N. Rega, J.M. Millam, M. Klene, J.E. Knox, J.B. Cross, V. Bakken, C. Adamo, J. Jaramillo, R. Gomperts, R.E. Stratmann, O. Yazyev, A.J. Austin, R. Cammi, C. Pomelli, J.W. Ochterski, R.L. Martin, K. Morokuma, V.G. Zakrzewski, G.A. Voth, P. Salvador, J.J. Dannenberg, S. Dapprich, A.D. Daniels, O. Farkas, J.B. Foresman, J.V. Ortiz, J. Cioslowski, D.J. Fox, Gaussian 09', Gaussian Inc, Wallingford CT, 2009.

[22] Y. Zhao, D.G. Truhlar, Acc. Chem. Res. 41 (2008) 157-167.

[23] Y. Zhao, D.G. Truhlar, Theor. Chem. Acc. 120 (2008) 215-241.

[24] P.J. Hay, W.R. Wadt, J. Chem. Phys. 82 (270-283) (1985) 299-310.

[25] L.E. Roy, P.J. Hay, R.L. Martin, J. Chem. Theory Comput. 4 (2008) 1029-1031.

[26] C.E. Check, T.O. Faust, J.M. Bailey, B.J. Wright, T.M. Gilbert, L.S. Sunderlin, J. Phys. Chem. A 105 (2001) 8111-8116.

[27] V. Barone, M. Cossi, J. Tomasi, J. Chem. Phys. 107 (1997) 3210-3221.

[28] V. Barone, M. Cossi, J. Phys. Chem. A 12 (1998) 1995-2001.

[29] (a) C.J. Cramer, Essentials of Computational Chemistry, 2nd ed., Wiley, Chichester, 2004:

(b) F. Jensen, Introduction to Computational Chemistry, 2nd ed., Wiley, Chichester, 2007.

[30] Z. Otwinowski, W. Minor, in: C.W. Carter, R.M. Sweet (Eds.), Methods in Enzymology, Vol. 276, Academic Press, London, 1997, pp. 307-326.

[31] R.H. Blessing, Acta Crystallogr., Sect. A 51 (1995) 33-38.

[32] A. Altomare, M.C. Burla, M. Camalli, G.L. Cascarano, C. Giacovazzo, A Guagliardi, A.G. Moliterni, G. Polidori, R.R. Spagna, J. Appl. Crystallogr. 32 (1999) 115-119.

[33] G.M. Sheldrick, Crystal Structure Refinement with SHELXL, Acta Crystallogr. C71 (2015) 3-8.

[34] M. Nardelli, J. Appl. Crystallogr. 28 (1995) 659.

[35] L.J. Farrugia, J. Appl. Crystallogr. 32 (1999) 837-838. 